\title{
Exploiting Friends-and-Neighbors to Estimate Coattail Effects*
}

\author{
Marc Meredith \\ University of Pennsylvania \\ marcmere@sas.upenn.edu
}

March 5, 2013

\begin{abstract}
Federalist democracies often hold concurrent elections for multiple offices. A potential consequence of simultaneously voting for multiple offices that vary with respect to scope and scale is that the personal appeal of candidates in a high-profile race may affect electoral outcomes in less salient races. In this paper I estimate the magnitude of such coattail effects from governors onto other concurrently elected statewide executive officers using a unique data set of county election returns for all statewide executive office elections in the United States from 1987 to 2010. I exploit the disproportionate support that candidates receive from geographically proximate voters, which is often referred to as the friends-and-neighbors vote, to isolate variation in the personal appeal of candidates. The point estimates from my preferred specifications show that a one-percentage-point increase in the personal vote received by a gubernatorial candidate increases their party's secretary of state and attorney general candidates vote shares by 0.1 to 0.2 percentage points. In contrast, personal votes for a secretary of state or attorney general candidate have no effect on the performance of their party's gubernatorial candidate or other down-ballot candidates.
\end{abstract}

${ }^{*}$ I thank Luke Reilly, Aakash Abbi, and Emily Thorson for providing excellent research assistance. I also thank Olle Folke, Alex Gelber, Jason Grissom, Jens Haimueller, Shigeo Hirano, Dan Hopkins, Greg Huber, Luke Keele, Jon Kolstad, John Lapinski, Matt Levendusky, Gabe Lenz, Todd Makse, Neil Malhotra, Erik Snowberg, and Jim Snyder, as well as seminar audiences at Caltech, NYU, Emory, the 2009 Yale Center for the Study of American Politics Conference, the 2010 Midwest Political Science Association Conference, and the 2010 State Politics and Policy Conference for useful discussions and assistance with data gathering. 


\section{Introduction}

Voters in most federalist countries elect representatives to serve in political institutions that vary in their scope and scale. Representatives in such multilevel governments are selected in a mix of concurrent and separate elections, often referred to as the electoral cycle. Previous research identifies a number of channels through which the electoral cycle can generate contamination effects such that electoral outcomes at one level of government are affected by a feature of another level of government. ${ }^{1}$ One contamination effect that has long interested academics, journalists, and political pundits is the coattail effect. Miller (1955) defines a coattail effect as the effect that the personal identity of a party's candidate in one election has on the performance of the party's candidates in concurrent elections. ${ }^{2}$ Coattails affect the chances that personally popular executives such as Ronald Reagan or Luiz Inácio Lula da Silva will come into office with a supportive legislature, which in turn has consequences for whether such leaders can enact their agendas. Coattails also have important implications for the structure of political parties, campaign finance, and the electoral incentives of representatives (Samuels, 2002, 2004).

Since the 1940s, scholars have tried to empirically test for the existence of coattails and to estimate the magnitude of their influence in a variety of contexts. Estimating these effects might seem like a straightforward exercise, but this is not the case because a number of factors - including voters' preferences and the state of macroeconomy - affect how a party's

\footnotetext{
${ }^{1} \mathrm{~A}$ high profile election can either provide or crowd out vote-relevant information in less salient concurrent elections (Freedman, Franz and Goldstein, 2004; Wolak, 2009). The mix of races on a ballot may affect the distribution of preferences of individuals who turn out to vote (Berry and Gersen, 2010), in part by changing parties and elites incentives to engage in mobilization (Cox, 1999). How voter preferences are translated into votes also differ when elections are held concurrently (Mondak and McCurley, 1994; Zudenkova, 2011). Thus, the electoral cycle may affect the entry decisions of candidates and parties (Shugart and Carey, 1992; Golder, 2006) and the incentives for candidates and parties to share resources and engage of other forms of coordination (Samuels, 2003; Hicken and Stoll, 2011).

${ }^{2}$ Although this definition is generally accepted in the American politics literature, sometimes the term "coattail effect" is used in the comparative politics literature to refer to any feature of one level of government that affects election outcomes at another level of government. For example, Ames (1994) refers to the relationship between local political control and national election outcomes as a coattail effect. Others refer to such cross-level spillovers as contamination or interaction effects (Herron and Nishikawa, 2001; Cox and Schoppa, 2002; Ferrara, Herron and Nishikawa, 2005; Hainmueller and Kern, 2008).
} 
candidates perform at both the top and bottom of the ballot. Regressions are typically used to control for the variables that are thought to affect both a party's top- and down-ballot performance, and then any remaining association between a party's top- and down-ballot vote share is interpreted as the coattail effect (Samuels 2003, 83). Unfortunately, it is difficult to observe, measure, and specify the proper functional relationship between all these variables. These unmeasured or mismeasured determinants of a party's down-ballot vote share are also likely to affect the party's vote shares in other races. When this happens, omitted variable bias will cause the expected association between a party's top- and down-ballot vote shares to be larger than the true coattail effect. Even if all of the other joint determinants of top- and down-ballot vote shares are properly included in a regression, additional problems arise when down-ballot candidates' coattails also affect the top-ballot race. In such cases, simultaneity bias will cause the expected association between top- and down-ballot vote shares to overstate the coattail effect. Consequently, previous research that interprets this association as a coattail effect is likely to overstate the importance of coattails.

In this paper I present a technique for overcoming this identification problem. Rather than trying to model all of the joint determinants of top- and down-ballot vote shares, I isolate variation in the personal votes received by candidates across different constituencies. A personal vote refers to a vote that is cast on the basis of a candidate's characteristics or record, rather than party (Cain, Ferejohn and Fiorina, 1990). Previous work shows that candidates tend to receive more personal votes from geographically proximate constituents, which is often referred to as friends-and-neighbors voting (Key, 1949; Lewis-Beck and Rice, 1983). Such forms of personal voting can provide variation in candidate performance that is unrelated to the unmeasured or mismeasured factors that affect both top- and down-ballot party choice. The resulting association between the personal vote received by a top-ballot candidate and the vote shares received by down-ballot candidates from his or her party can be used to construct an estimate of the coattail effect that is not upwardly biased by omitted variable or simultaneity bias. 
I use this approach to estimate the magnitude of coattail effects in concurrent U.S. statewide executive-office elections from 1987 to 2010. Data on the location of birth and residence of gubernatorial, secretary of state, and attorney general candidates are used to isolate variation in the performance of both top- and down-ballot candidates in a county that is due to friends-and-neighbors voting. This variation is related to the performance of their party in other concurrent races. My point estimates show that a one-percentagepoint increase in the personal vote received by a party's gubernatorial candidate in a county increases the vote share received by the party's secretary of state or attorney general candidate by 0.1 to 0.2 percentage points. These instrumental variable (IV) point estimates are smaller than the point estimates from comparable ordinary least squares (OLS) regressions, although generally not statistically distinguishable. In contrast, OLS and IV specifications produce estimates of secretary of state and attorney general candidates' coattails that are both statistically and substantively different. These findings suggest that although coattails do exist in some contexts, previous work likely inflates their influence and may even incorrectly identify their presence.

\section{Relevant Literature}

A coattail effect occurs when an individual who would usually support a down-ballot candidate from party A instead votes for the down-ballot candidate from party B because he or she supports the top-ballot candidate from party B. ${ }^{3}$ One potential explanation for such behavior is that people generally dislike holding conflicting beliefs, such as simultaneously supporting Democratic and Republican candidates (Mondak and McCurley, 1994). As such, voters may prefer to cast down-ballot votes for candidates from the party of their preferred top-ballot candidate. Ballot features may also encourage voters to cast straight-ticket ballots and support the party of their preferred top-ballot candidate in down-ballot elections.

\footnotetext{
${ }^{3}$ Campbell and Miller (1957) argue that coattails come into being "because the personal appeal, the magnetism of the presidential candidate, can be translated into the sort of allegiance which commands the voter to do his bidding and give[s] support to his cohorts who follow him on the ballot" (309).
} 
Campbell and Miller (1957) contend that the straight-party option, which allows voters to cast a ballot for a party's candidate in every concurrent election with a single vote, may increase the prevalence of straight-ticket voting. ${ }^{4}$

Coattails can also result from top-ballot candidates mobilizing a party's supporters. Campbell (1960) distinguishes between a party's core supporters, who generally vote, and peripheral supporters, who often require additional political stimulation to turn out. The attractiveness of a top-ballot candidate is one of the political stimulants that Campbell highlights as an important determinant of whether these peripheral supporters ultimately vote. Coattails arise because these peripheral supporters are also likely to support their party's down-ballot candidates once at the polls.

Early studies of coattail effects by Bean (1948) and Moos (1952) look at the relationship between a party's performance in U.S. presidential and congressional elections. Miller (1955) cautions against interpreting these studies as definitive evidence of coattail effects, in part because there are factors besides coattails that could result in a voter supporting a presidential and congressional candidate from the same party. More recent work on coattail effects uses regression analysis in an attempt to control for these factors.

Studies of coattail effects generally employ one of three different estimation approaches: OLS regressions, structural modeling, or IV regressions. ${ }^{5}$ The most common form of OLS analysis is a cross-sectional regression of a party's down-ballot vote share in an electoral district on a host of district-level variables that are thought to relate to support for the party in the down-ballot election, including the party's vote share in the district in a top-ballot election. The coefficient on the party's top-ballot vote share generally is interpreted as the coattail effect. Other studies run this analysis using individual-level vote choice data, again interpreting the coefficient on top-ballot party vote choice as the coattail effect. Another OLS approach is a time-series regression of a party's aggregate down-ballot vote share on

\footnotetext{
${ }^{4}$ Likewise, Rusk (1970) argues that using office-bloc, rather than party-column, ballots reduces straightticket voting.

${ }^{5}$ Table A.1 in the supplemental appendix presents a selected summary of coattail effects estimated using one of these three approaches.
} 
a party's vote share in a top-ballot race, with the coefficient on the party's top-ballot vote share interpreted as the coattail effect.

The OLS regression approach is problematic because factors other than coattail effects, such as voters' ideology and the state of the economy, also contribute to the positive association between the support received by a party's candidates running for top- and down-ballot offices. These joint determinants are challenging to observe and measure, and it can be difficult to specify the proper functional relationship between these variables and down-ballot candidate performance. The unobserved determinants of down-ballot candidate performance are also likely to affect the performance of the party's top-ballot candidate. Consequentially, the coefficient obtained when regressing a party's down-ballot vote share on its top-ballot vote share risks an overstatement of the true coattail effect. The importance of properly accounting for these joint determinants when estimating a coattail effect is demonstrated by studies that produce substantially different estimates of coattail effects in the same context. For example, Mondak (1993) and Flemming (1995) estimate the effect of presidential coattails on a similar set of open-seat U.S. House races. Where Mondak finds that a one-percentagepoint increase in a party's presidential vote share associates with a 0.82 percentage point increase in the party's House candidates' vote shares, Flemming estimates an association of only 0.29 percentage points.

Other studies employ structural models to estimate the presidential coattail effect on House elections. Kramer (1971) estimates a joint model of aggregate presidential and House vote shares that includes a presidential coattail effect. The model is identified by an assumption that the unobserved determinants of a party's House vote share have an equal effect on the party's presidential and House vote shares. Kramer's point estimates imply that a onepercentage-point increase in the personal vote received by a presidential candidate increases the vote share received by their party's House candidates by 0.3 percentage points. Ferejohn and Calvert (1984) weaken Kramer's assumption of a common unobservable determinant of presidential and House vote shares, estimating a range of coattail effects depending on the 
assumed correlation between these unobservable determinants of presidential and House vote shares. Their point estimates suggest that a one-percentage-point increase in the personal vote received by a presidential candidate increases the vote share received by their party's House candidates by between 0.24 and 0.51 percentage points.

Fair (2009) shows that these structural models are sensitive to model specification. Using a similar model to Kramer (1971), Fair's point estimates indicate that a one-percentage-point increase in the personal vote received by a presidential candidate reduces his party's House vote share by almost 0.5 percentage points. Using the approach of Ferejohn and Calvert (1984) his point estimates range between a -0.71- and a 0.8-percentage-point change in a party's House vote share because of a one-percentage-point increase in the personal vote received by their presidential candidate.

Finally, Calvert and Ferejohn (1983) use an IV approach to estimate the effect of reported U.S. presidential vote choice on reported House vote choice. They isolate personal votes for the president by instrumenting for presidential vote choice with a measure constructed from responses to an open-ended survey question "is there anything in particular about (name of candidate for president) that might make you want to vote for or against him." Their estimates suggest that a one-percentage-point increase in the probability of a personal vote for a presidential candidate increases the probability of supporting the House candidate of the same party by 0.5 percentage points. ${ }^{6}$

One concern with Calvert and Ferejohn's 1983 approach is that some reported likes and dislikes are rationalizations of vote choice (Rahn, Krosnick and Breuning, 1994). As a result, reported likes and dislikes are likely related to omitted variables resulting from imperfect

\footnotetext{
${ }^{6}$ Related recent literature uses close election regression discontinuity designs to look at how the party of incumbent elected officials affects voting in other races. Hainmueller and Kern (2008) find that German voters are more likely to support the party of their current single-member district representative in the next proportional representation election. Similarly, Ade and Freier (2011) find that German voters are more likely to support the party of the incumbent mayor in the next town council election in provinces with concurrent mayoral and town council elections, but not in provinces with separate mayoral and town council elections. Folke and Snyder (2012), on the other hand, find that the party winning the governor's office loses seats in midterm elections for U.S. state legislatures. Finally, Broockman (2009) finds that there is no increase in the likelihood that U.S. voters, in the next presidential election, will support the candidate belonging to the same party as their House representative elected in the midterm election.
} 
measurement of variables such as party identification. This calls into question whether this instrument isolates variation in the personal vote received by top-ballot candidates. This variation must be isolated in order for their instrument to satisfy the necessary exclusion restriction for IV to consistently estimate the coattail effect.

Like Calvert and Ferejohn (1983), I use an IV approach that attempts to isolate personal votes for top-ballot candidates with the goal of identifying a coattail effect. I focus specifically on the increase in personal votes that candidates receive from geographically proximate voters. One of the first and best known treatments of how the geographic proximity of candidates affects voter behavior is Key's (1949) work on primaries in the American South in the first half of the twentieth century. Key coined the term "friends-and-neighbors voting" to describe the increased support that candidates receive near their place of birth and residence. Subsequent work shows that candidates receive disproportionate support from geographically proximate voters across a broad spectrum of elections worldwide, including in the American statewide executive-office elections that are the focus of this paper (Rice and Macht, $1987 a$; Gimpel et al., 2008). The first stage of my IV regressions estimates the increase in the personal vote that candidates received in counties near their place of birth and residence. The second stage of the IV regressions relates these friends-and-neighbors votes to the vote shares that down-ballot candidates from their party received in these counties in concurrent elections.

Although the approach presented in this paper has a number of advantages over previous attempts to isolate coattail effects, these advantages come with some costs associated with using IV. The validity of the instruments hinges on the assumption that, conditional on the control variables, coattail effects are the only channel through which the place of birth or residence of a party's gubernatorial candidate affects the vote shares received by its downballot candidates. Ultimately this is an untestable assumption, but I conduct robustness and placebo tests to help justify the assumption, as well as sensitivity analysis that estimates the coattail effect under an alternative set of assumptions. The local average treatment ef- 
fect (LATE) property of IV also potentially limits the generalizability of the coattail effects estimated using my instruments (Imbens and Angrist, 1994). The LATE property implies that IV estimates are specific to the observations affected by the instruments, which in this case are counties with geographically proximate candidates. While the demographics of candidates' home counties are demonstrated to be representative of their state on most dimensions, there is no guarantee that the coattail effects resulting from friends-and-neighbors voting are of a similar magnitude as the coattail effects resulting from other forms of personal voting.

\section{Data}

I collected two new datasets that I use to estimate the effect of gubernatorial coattails on down-ballot U.S. statewide executive office elections. County election returns were collected for all partisan statewide executive office election outcomes from 1987 to $2010 .{ }^{7}$ These data are supplemented with the county of birth and residence for nearly all candidates for attorney general, governor, and secretary of state in that same time period.

\subsection{Election Data}

County election return records are usually maintained by the office in charge of running a state's elections, which is typically the secretary of state's office. Whenever possible, data were collected from the websites of these offices. Data that were unavailable on state websites, which is often the case for elections in the 1980s and 1990s, were collected from a variety of alternate sources, including hard copies obtained from the election officials, state Blue Books, and other existing online election archives. ${ }^{8}$ Using these data I construct off $_{c, t}$,

\footnotetext{
${ }^{7}$ Races for multi-member boards such as a corporation commission or a board of regents were excluded.

${ }^{8}$ Alaska, Hawaii, Maine, New Hampshire, New Jersey, and Tennessee are excluded from the analysis because these states do not hold any elections for down-ballot statewide executive offices. Oregon and Pennsylvania are excluded because none of their down-ballot statewide executive office elections are held concurrently with their gubernatorial election. Louisiana is excluded because of the electoral system used to select statewide executive officers. Delaware is excluded from the analysis because there are only three
} 
the two-party vote share of the Democratic candidate running for office off in county $c$ at time $t$.

As discussed in section 3.2, candidates' place of birth and residence were collected for one selected down-ballot race in each state. In states that concurrently elect their governor and secretary of state, data were collected for the secretary of state candidates. For states that do not, data were collected for the attorney general candidates. I define $d o w n_{c, t}$ as the Democratic candidate's percentage of the two-party vote share in county $c$ at time $t$ in this selected down-ballot race and $\overline{d o w n}_{c, t}$ as the average Democratic percentage of the two-party vote cast in all statewide executive office races except the gubernatorial race in county $c$ at time $t .^{9}$

\subsection{Home County Data}

I attempted to collect data on county of birth and county of residence for all gubernatorial and selected down-ballot candidates in each election held between 1987 and 2010. The primary source of data was biennial publications of Who's Who in American Politics, each edition of which has thousands of short biographical records for individuals active in politics. I extracted from these records both a candidate's county of birth and county of residence. For 2010 candidates, I relied on questionnaires distributed by the website Project Vote Smart. ${ }^{10}$

A drew on several secondary sources, including archived newspaper articles, Wikipedia, Ballotpedia, Political Graveyard, and archived candidate websites, to obtain place of birth and residence for candidates who are not listed in Who's Who in American Politics or don't provide information to Project Vote Smart. ${ }^{11}$ Ultimately, I observe place of birth for $99 \%$ of gubernatorial candidates and $83 \%$ of candidates in the selected down-ballot race, and place

counties in the state. In the remaining 40 states, 14 state-year observations are excluded because a thirdparty gubernatorial candidate received more than $15 \%$ of the statewide vote.

${ }^{9}$ State-year-office observations where only one of the two major parties competed or a third-party candidate received more than $15 \%$ of the vote are excluded when constructing $\overline{\text { down }}_{c, t}$.

${ }^{10}$ In cases where the biography or questionnaire indicates that the candidate is an incumbent or has previously held another statewide political office, the candidate's county of residence was coded as the place of residence prior to entering a statewide political position.

${ }^{11}$ See Brown (2011) for a discussion of the merits of using Wikipedia for candidate biographical information. 
of residence for $100 \%$ of gubernatorial candidates and $97 \%$ of candidates in the selected down-ballot race. ${ }^{12}$

By combining these data on county of birth and residence, I construct measures predicting which candidate, if either, is likely to receive more friends-and-neighbors support in a given county in a given race. The intuition behind my measures is that if one party's candidate was born or resides in close proximity to a given county and the other party's candidate was neither born in nor resides near that county, the former party's candidate should receive more friends-and-neighbors votes in that county.

Turning this intuition into a measure of geographic advantage requires that I specify both the geographic proximity of a candidate to a county and how this geographic proximity translates into a geographic advantage. The geographic proximity of the Democratic candidate for office off at time $t$ to county $c$ is captured using DemDist $t_{c, t, o f f}$. DemDist Det,off $_{\text {f }}$ measures the distance between county $c$ and a county where the Democratic candidate for office off at time $t$ was either born or resides. ${ }^{13}$ The geographic proximity of the Republican candidate for office off at time $t$ to county $c$ is captured in an analogous manner with RepDist $_{c, t, \text { off }}$. Two approaches are used to translate these distance measures into a measure of a candidate's geographic advantage in a county. The most straightforward, Home c,t,off $_{\text {, }}$ indicates whether one party's candidate was born in or resides in a county in which the other party's candidate was neither born nor resides. Specifically,

\footnotetext{
${ }^{12}$ There are some systematic patterns to the missing data. Winning candidates are more likely to be listed in Who's Who in American Politics or Wikipedia, making it easier to find information about them than losing candidates. Because newspaper archives are less comprehensive in the 1980's and 1990's than in the 2000 's, there is more missing data from earlier time periods. Finally, because place of birth information was more difficult to obtain for candidates who were not born in the state in which they are running for office, I suspect that a disproportionate number of the remaining missing places of birth are cases where candidates were not born in the state in which they are running.

${ }^{13}$ Let DemDistBorn Deft, off $_{\text {and DemDistReside }}, t$, off be the number of miles between county $c$ and the county in which the Democratic candidate running for office off at time $t$ was born and resides, respectively. The number of miles between county $A$ and county $B$ is calculated using the formula $\arccos \left(\sin \left(\operatorname{lat}_{a} * \pi / 180\right) *\right.$ $\sin \left(\right.$ lat $\left._{b} * \pi / 180\right)+\cos \left(\right.$ lat $\left._{a} * \pi / 180\right) * \cos \left(\right.$ lat $\left._{b} * \pi / 180\right) * \cos \left(\left(\right.\right.$ long $_{a}-$ long $\left.\left.\left._{b}\right) * \pi / 180\right)\right) * 6371 * 0.621371192$, where the latitudes and longitudes of the geographic center of counties $A$ and $B$ are measured using coordinates provided by the US Census. DemDist $t_{c, t, o f f}$ is defined as the smaller of these two distances. In cases where the Democratic candidate was not born in the state in which he or she is running for office, DemDist ${ }_{c, t, o f f}$ is set equal to DemDistReside ${ }_{c, t, o f f}$.
} 


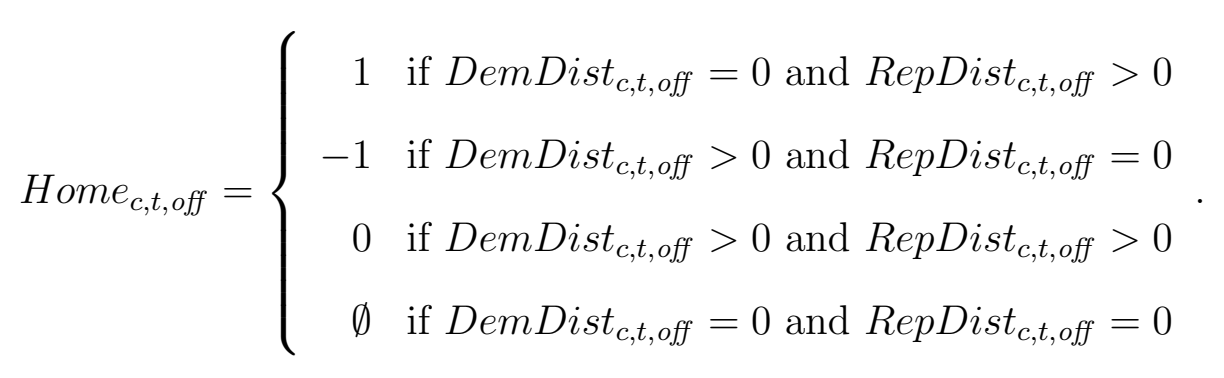

The second approach takes a broader view of what constitutes a geographic advantage in a county. Within $50_{c, t, \text { off }}$ indicates whether one party's candidate for office off at time $t$ was born or resides in a county within 50 miles of county $c$, while the other party's candidate neither was born nor resides in a county within 50 miles of the county. Specifically,

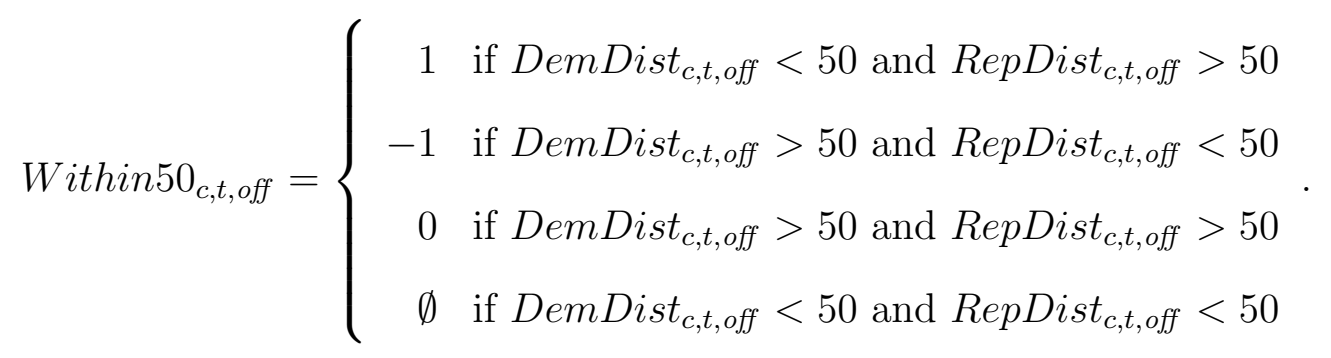

It is not clear which party's candidate, if either, would have a friends-and-neighbors voting advantage in county $c$ when both parties candidates either were born in or reside in that

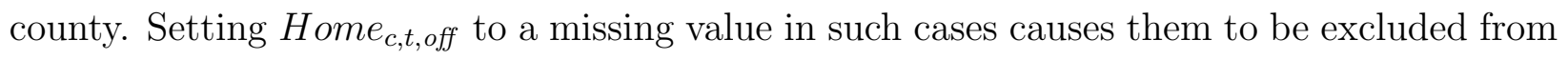
the analysis when $H_{\text {ome }}, t$, off is included as a regressor. Likewise, setting Within $50_{c, t, \text { off }}$ to a missing value when both parties' candidates were born in or reside in a county within 50 miles of county $c$ causes such cases to be excluded from the analysis when Within $50_{c, t, o f f}$ is included as a regressor.

\subsection{Descriptive Statistics}

Table 1 shows that 210 elections are observed with both a valid gubernatorial and selected down-ballot election, producing a total of 14,656 observations in 2,763 counties. There are 441 cases where one party's gubernatorial candidate was born in or resides in a given county. A total of 285 of the 2,763 counties in the dataset have at least one case where one party's 
gubernatorial candidate was born in or resides in that county. There also are 49 cases where both gubernatorial candidates share a common home county.

Table 2 shows that candidates' home counties are similar to their states in terms of the county's share of population, per-capita income, and John Kerry's vote share in the 2004 presidential election. This similarity reduces concerns that the coattail effect identified by my instruments is unrepresentative of the coattail effect in the general population of counties. However, home counties are somewhat more densely populated and substantially more likely to contain the state capital. Democratic candidates are particularly likely to have been born in or reside in densely populated counties and the county that contains the state capital. Candidates also tend to come from counties that were more supportive of their party's candidate in the 2004 presidential election than was their state at-large.

Figure 1a shows that a party's candidates generally perform better in a home county of their gubernatorial candidate. Democratic gubernatorial candidates outperform their statewide vote share by an average of 8.2 percentage points in their home counties, as they receive an average of $56.3 \%$ of the vote in a home county as compared to $48.1 \%$ of the vote statewide. Similarly, Republican gubernatorial candidates outperform their statewide vote share by an average of 5.2 percentage points in their home counties. Selected downballot candidates also receive more votes in these counties, with Democratic and Republican selected down-ballot candidates outperforming their statewide vote share by an average of 4.9 and 2.5 percentage points respectively in a home county of their party's gubernatorial candidate.

A party's candidates may do better in a home county of their gubernatorial candidate because their gubernatorial candidate attracts a number of personal votes in the county, some of which spillover onto their party's down-ballot candidates because of coattails. This disproportionate support for a party's gubernatorial and down-ballot candidates could also reflect differences in the party preferences of voters in the home counties of gubernatorial candidates. One way of separating these two potential explanations is to look at how a party's 
candidates perform in these same counties in elections where neither party's gubernatorial candidate is from the county. If similar patterns are observed in these counties in elections where neither party's gubernatorial candidate is from the county, this suggests that party preferences are likely to cause the patterns observed in Figure 1a. Alternatively, if a party's candidates generally do better in a county when the party's gubernatorial candidate is from the county, this suggests that personal voting and coattails are part of the explanation.

Both Figure 1a and Figure 1b show election results from the same counties. However, Figure 1b shows how a party's candidates perform in the counties highlighted in Figure 1a in a different set of elections. In the election results shown in Figure 1b, neither party's gubernatorial candidate was born in or resides in the county. The patterns displayed in Figure $1 \mathrm{~b}$ are consistent with the hypothesis that while party preferences play an important role, personal voting and coattails also explain some of the increase in a party's vote share in a home county of their gubernatorial candidate. The differences between county and statewide performance are larger in both the gubernatorial and down-ballot races in Figure 1a. For example, while Figure 1a shows that Democratic gubernatorial candidates outperform their statewide vote share by an average of 8.2 percentage points in a home county, Figure 1b shows that other Democratic gubernatorial candidates only outperform their statewide vote share by an average of 4.6 percentage points in these same counties. This 3.6 percentage point difference suggests the presence of a substantial number of personal friends-and-neighbors votes. The IV method developed in the next section is based on the premise that if gubernatorial coattails exist, these personal friends-and-neighbors votes should also cause Democratic down-ballot candidates to perform better in a county when it is a Democratic gubernatorial candidate's home county. Consistent with this prediction, Democratic down-ballot candidates outperform their statewide vote share by an average of 4.9 percentage points when it is the home county of the Democratic gubernatorial candidate, as compared to 4.5 percentage points when it is not. Likewise, Republican gubernatorial and down-ballot candidates perform relatively better in a county when it is a Republican 
gubernatorial candidate's home county.

\section{Coattail Effects}

\subsection{Empirical Specification}

This subsection explains how the increase in vote share that candidates receive in and near their place of birth and residence can be used to estimate coattail effects. The specific coattail effect of interest is how increases in personal votes cast for a gubernatorial candidate in a county also increases the vote share of down-ballot candidates from the gubernatorial candidate's party in that county. As was previously discussed, estimating this relationship is complicated by the presence of a number of variables, some of which are difficult to observe, that jointly affect support for a party's gubernatorial and down-ballot candidates in a county. Below I show how knowledge of a candidate's place of birth and residence and panel data can be used to overcome this identification problem.

Equation 1 presents a specification often used in previous work to identify coattail effects. The down-ballot Democratic vote share in county $c$ at time $t$ is modeled as a separable linear function of the Democratic vote share in the concurrent gubernatorial election, $g_{0} v_{c, t}$, a vector of control variables, $X_{c, t}$, and an unobservable component, $\epsilon_{c, t}$. This model is typically estimated by OLS, with $\hat{\beta}$ interpreted as the estimated coattail effect. Such an interpretation relies on $X_{c, t}$ containing all of the joint determinants of a county's general support for Democratic candidates. If some of these variables are unobserved or if the functional relationship between these variables and the down-ballot vote share is misspecified this calls into question whether the error term is truly unrelated to the gubernatorial vote share after conditioning on the control variables. The condition that $E\left[\epsilon_{c, t} \mid g o v_{c, t}, X_{c, t}\right]=0$ must hold for OLS to consistently estimate the coattail effect. It is important to note that this condition will also be violated if coattails also operate in the opposite direction such that down-ballot candidates' vote shares affect their party's performance in the gubernatorial 
election.

$$
\operatorname{down}_{c, t}=\beta \operatorname{gov}_{c, t}+\theta X_{c, t}+\epsilon_{c, t}
$$

Identifying and collecting all of the joint determinants of a party's gubernatorial and down-ballot vote shares in a county is nearly impossible, as discussed in section 2 . I instead use IV to isolate variation in the personal votes cast for gubernatorial candidates across counties. A set of instruments, $Z_{c, t}$, that affect a gubernatorial candidate's personal support in a county can potentially identify $\beta$ when the unobserved determinants of down-ballot vote share are conditionally independent of the instruments. This exclusion restriction is denoted mathematically as $E\left[\epsilon_{c, t} \mid Z_{c, t}, X_{c, t}\right]=0$. A randomly assigned treatment that affects a gubernatorial candidate's personal support in a county is the ideal instrument because it is assigned independent of a party's expected down-ballot vote share in the county. Because such an experiment does not exist, I next consider other variables that affect the personal votes a gubernatorial candidate receives in a county. Unlike a randomly assigned treatment, it is generally incorrect to assume that such variables are assigned independent of a party's down-ballot vote share. However, focusing on the right set of instruments can reduce the set of control variables that are necessary in order for the exclusion restriction to hold.

Equation 2 is an example of a first-stage equation that instruments for gubernatorial vote share using information about gubernatorial candidates' place of birth and residence. This first-stage equation instruments for the gubernatorial vote share in the county using $H_{\text {ome }}$, , gov , the variable that indicates whether one party's gubernatorial candidate was born in or resides in the county (i.e., $Z_{c, t}=H_{o m e} e_{c, t, g o v}$ ). For Home $e_{c, t, g o v}$ to be potential instrument for gubernatorial vote share, it is necessary that gubernatorial candidates receive additional personal votes in their county of birth and residence (i.e., $\psi>0$ ). Figure 1 presented preliminary evidence that this is the case. However, this alone does not make Home $e_{c, t, g o v}$ a good instrument. The exclusion restriction that must hold for the system of equations 1 and 2 to identify the gubernatorial coattail effect is that $E\left[\epsilon_{c, t} \mid H o m e_{c, t, g o v}, X_{c, t}\right]=0$. Explained 
in words, this exclusion restriction requires that any relationship between the unobserved determinants of down-ballot vote share and the place and birth and residence of gubernatorial candidates is captured by the control variables. Figures $1 \mathrm{a}$ and $1 \mathrm{~b}$ show that candidates tend to come from counties that are predisposed to support their party. Thus, the validity of this exclusion restriction hinges on the ability of the control variables to fully account for these differences in the party preferences of voters in the counties near candidates' place of birth and residence.

$$
\operatorname{gov}_{c, t}=\psi \text { Home }_{c, t, g o v}+\zeta X_{c, t}+\nu_{c, t}
$$

Equation 3 shows how I parameterize the controls, $\zeta X_{c, t}$, in my baseline specification. Following Levitt and Wolfram (1997) and Ansolabehere and Snyder (2002), I use a combination of fixed effects to model the expected gubernatorial vote share in a county in a given election. An election fixed effect, $\lambda_{s(c), t}$, controls for the differences in relative quality of Democratic and Republican gubernatorial candidates within state $s(c)$ across elections. A county fixed effect, $\lambda_{c}$, controls for differences in the gubernatorial normal vote across counties within a state. ${ }^{14} \mathrm{I}$ also include a county time trend, $\tau_{c}$, in some specifications to account for Miller's (1979) critique of measures of the normal vote that do not account for the possibility of changes across time. Finally, I include $H_{o m e}, t$, down, an indicator for whether a party's down-ballot candidate was either born in or resides in the county.

$$
\zeta X_{c, t}=\lambda_{s(c), t}+\lambda_{c}+\tau_{c} t+\delta H_{o m e}, t, d o w n
$$

Equation 4 shows that I parametrize $\theta X_{c, t}$ in an analagous fashion to $\zeta X_{c, t}$ when estimating the second-stage equation, as is required in IV estimation. $\gamma_{s(c), t}$ controls for the differences in relative quality of Democratic and Republican down-ballot candidates within state $s(c)$ across elections, $\gamma_{c}$ controls for differences in the down-ballot normal vote across

\footnotetext{
${ }^{14}$ Converse (1966) defines the normal vote as the long-run tendency of an area to support a party's candidate.
} 
counties within a state, and $\omega$ accounts for the increase in vote-share down-ballot candidates receive in their county of birth or residence.

$$
\theta X_{c, t}=\gamma_{s(c), t}+\gamma_{c}+\phi_{c} t+\omega \text { Home }_{c, t, d o w n}
$$

I estimate the system of equations 1 and 2 using a number of different combinations of instruments to examine the robustness of the results obtained using this baseline specification. Some specifications also include $\operatorname{Within} 50_{c, t, g o v}$, the indicator for whether a county is within 50 miles of a home county of one candidate, as an instrument to exploit the smaller increase in personal votes that candidates receive in other counties near their place of birth and residence. Other specifications include the interactions between Home $_{c, t, g o v}$ and the population of the county as instruments to exploit the fact that friends-and-neighbors voting is more prevalent in less populated counties (Rice and Macht, 1987a). Including multiple instruments allows for the use of overidentification tests to examine whether these different instruments generate similar estimates of the coattail effect. ${ }^{15}$ Standard errors are clustered by county when estimating the system of equations 1 and 2 to account for autocorrelation in the place of birth and residence of a party's candidates across time.

\subsection{Results}

\subsubsection{Baseline Results}

Table 3 presents estimates of the gubernatorial coattail effect estimated using a variety of OLS and IV specifications. The OLS regressions find substantial positive associations when a party's down-ballot vote share in a county is regressed on the party's vote share in a concurrent gubernatorial election. Column 1 shows that a one-percentage-point increase in a party's gubernatorial vote share in a county associates with 0.839 (s.e. 0.008) percentagepoint increase in the party's down-ballot vote share when no controls are included to account

\footnotetext{
${ }^{15}$ These overidentification tests require an additional assumption that coattail effects are homogenous across the populations that are differentially affected by the instruments.
} 
for a county's general political tendencies. Including county fixed effects (column 2) reduces this estimate to 0.438 (s.e. 0.012), with a further reduction to 0.263 (s.e. 0.014) when county time trends are also included (column 3). It is on the basis of these types of regressions that some previous work infers that coattails from top-ballot candidates affect down-ballot races. However, Table 4, which presents estimates of the coattail effect from the selected downballot candidate onto their party's gubernatorial candidate, shows that there is a potential problem with interpreting these coefficients as coattail effects. While theories of coattails predict that secretary of state and attorney general candidates should have less, if any, affect on gubernatorial elections, Table 4 shows that a one-percentage-point increase in a party's down-ballot vote share associates with a 0.717 (s.e. 0.009), 0.468 (s.e. 0.013 ), and 0.328 (s.e. 0.019) percentage-point increase in the party's gubernatorial vote share when county fixed effects are excluded, county fixed effect are included, and time-trended county fixed effects are included. This pattern suggests that there may be unobserved variables affecting the vote shares of both gubernatorial and down-ballot candidates.

Gubernatorial coattails are also found to affect down-ballot races in my baseline IV specifications. The first-stage regression presented in column four of Table 3 estimates that gubernatorial candidates receive a 3.7 (s.e. 0.4) percentage point increase in their vote share in counties where they were born in or reside in prior to entering statewide office when county time trends are excluded. The F-statistic testing the hypothesis that the place of birth and residence of gubernatorial candidates have no explanatory power on gubernatorial vote shares is 75.17 , which is substantially larger than what Stock, Wright and Yogo (2002) suggest is necessary to avoid bias due to weak instruments. Using this instrument, I find that a one-percentage-point increase in the personal vote increases their party's down-ballot candidate's vote share by 0.216 (s.e. 0.079 ) percentage points (column 4). ${ }^{16}$ Including county time trends slightly increases the estimated first-stage effect of gubernatorial home counties on gubernatorial vote share from 3.7 to 3.8 (s.e. 0.5 ) percentage points, while slightly

\footnotetext{
${ }^{16}$ The reduced form of all IV analyses are reported in the supplemental appendix.
} 
reducing the estimated coattail effect to 0.163 (s.e. 0.071 ) percentage points (column 5 ). ${ }^{17}$ The stability of both my first-stage and IV coefficients to the inclusion of county time trends supports my claim that only a sparse set of control variables are necessary to capture the joint determinants of gubernatorial home counties and down-ballot vote shares.

Columns 6 and 7 of Table 3 show that coattail effect estimates are slightly smaller, but still statistically significant at conventional levels, when an indicator for a county being within 50 miles of a home county is also used as an instrument. As compared to a county that is more than 50 miles away from a home county, gubernatorial candidates are estimated to receive an additional 4.7 (i.e., $3.4+1.3)$ percentage points of vote share in a home county and an additional 1.3 (s.e. 0.1 ) percentage points of vote share in a county that is within 50 miles of a home county when county time trends are excluded. Using these instruments, the estimated gubernatorial coattail effect is 0.136 (s.e. 0.054 ) percentage points. The p-value on the overidentification test is 0.505 , indicating that the null hypothesis that the coattail effect estimated by the two instruments is the same cannot be rejected. Again including county time trends slightly increases the estimates of the friends-and-neighbors vote and slightly decreases estimates of the coattail effect.

Previous work by Rice and Macht (1987a) finds that the magnitude of the home-county advantage is larger in less populated counties. Using instruments that account for this heterogeneity could improve the efficiency of the IV estimates, although risks increasing their susceptibility to bias due to weak instruments. As expected, columns 8 and 9 of Table 3 shows that gubernatorial candidates' vote shares increase by about six percentage points in home counties that contain fewer than 100,000 people, but only by about two

\footnotetext{
${ }^{17}$ Standard errors that are clustered by county and election-year using the approach of Cameron, Gelbach and Miller (2011) are of a very similar magnitude. Two-way clustering reduces the standard error on the coattail effect from 0.079 to 0.077 when time trends are excluded and increases the standard error from 0.071 to 0.072 when time trends are included. Running the analysis only on the restricted sample of 285 counties in which there is over-time variation as to whether there is a home county gubernatorial candidate also produces coattail effect estimates of 0.218 (s.e. 0.068) and 0.140 (s.e. 0.068 ) when county time trends are included and excluded respectively. The fact that the standard errors are slightly smaller using this restricted sample shows that including a large number of counties without variation in the instrument does not lead to underestimated standard errors.
} 
percentage points in home counties that contain more than 100,000 people. Consistent with my expectations, using the interactions between home county and population size slightly reduces the standard errors on my coattail effect estimates. When these interactions are used as instruments the estimated coattail effect is slightly larger than in the baseline specification when county time trends are excluded, and slightly smaller than in the baseline specification when county time trends are included.

I conclude this subsection by examining whether two characteristics of state elections moderate the gubernatorial coattail effect. While some states hold their gubernatorial election concurrently with the presidential election, others states elect their governor in the midterm or an odd year election. Because a candidate's coattails are thought to be longest when they are running for the most prominent office on the ballot (Campbell, 1991), I hypothesize that gubernatorial coattails will be smaller when the election is held concurrent with the presidential election. However, columns 10 and 11 of Table 3 shows no significant difference in the magnitude of gubernatorial coattails in states that elect their governor concurrently with the president. States also vary in whether they give voters the option to cast a straight-party ballot, a feature which may magnify the coattail effect by making it easier for voters to select down-ballot candidates of the same party (Campbell and Miller, 1957). Columns 12 and 13 of Table 3 show somewhat larger estimates of the gubernatorial coat-

tail effect in states with the straight party option, with this difference bordering on being statistically significant when county time trends are included.

\subsubsection{Robustness Tests}

The results presented in section 4.2.1 suggest that while the gubernatorial coattail effect does exist, it is somewhat smaller than what is implied by OLS associations. This finding is subject to the standard concerns highlighted by Sovey and Green (2011) about using observational instrumental variables like the place of birth and residence of gubernatorial candidates. The primary threat to the internal validity of my IV approach is that candidates 
may come from counties where a party's candidates are going to perform better than my models predict even absent any coattail effects. For example, county fixed effects and time trends may not sufficiently control for the tendency of candidates to come from home counties that are generally supportive of their party. Alternatively, candidates may win their party's primary partially because their local area is unusually supportive of their party in a given year. Either of these occurrences would result in a violation of the exclusion restriction, which requires that the unobserved determinants of down-ballot vote shares must be conditionally independent of the county of birth and residence of gubernatorial candidates.

One strategy for determining whether my instruments satisfy the exclusion restriction is to look at whether my estimates of the home-county advantage are affected by the inclusion of county specific time trends. If a party's gubernatorial candidates tend to come from areas where the party is currently popular then shifts in the place of birth and residence of a party's candidates across time should relate to shifts in the relative popularity of the party across counties. Thus, we would expect to see the first-stage relationship of gubernatorial home county on gubernatorial vote share being attenuated by the inclusion of county specific time trends. However, the estimated increase in a gubernatorial candidate's personal vote in their home counties is nearly an identical 3.73 (s.e. 0.45 ) and 3.79 (s.e. 0.52 ) percentage points when county time trends are excluded and included respectively. A similar pattern is observed in counties near gubernatorial candidates' home counties. ${ }^{18}$

Additional analyses further investigate the plausibility of the assumption that the unobserved determinants of down-ballot vote shares are conditionally independent of the county of birth and residence of gubernatorial candidates. I first test whether a party's candidates perform better in their gubernatorial candidates' home counties in elections that take place just before or just after a gubernatorial election. If gubernatorial candidates tend to come from home counties in which their party is currently popular, other candidates from their

\footnotetext{
${ }^{18}$ Similar results are found when quadratic, rather than linear, county time trends are used. Using such a specification, gubernatorial candidates are estimated to receive a 3.87 (s.e. 0.60) increase in vote share in their home counties. The estimated gubernatorial coattail effect using this specification is 0.231 (s.e. 0.078 ).
} 
party should also do better in these home counties in temporally proximate elections. I test this relationship by reestimating the first-stage regressions in Table 3 and setting the dependent variable as the two-party Democratic presidential vote share in the most proximate presidential election to the gubernatorial election. ${ }^{19}$ Because gubernatorial candidates tend to come from counties that are predisposed to support their party, it is not surprising that presidential candidates receives almost a three percentage point higher vote share in the home counties of their party's gubernatorial candidates. However, once county fixed effects are included as controls, a presidential candidate performs 0.03 (s.e. 0.30) percentage points worse than expected in home counties of their party's gubernatorial candidate. ${ }^{20}$ Observing that a presidential candidate performs no better than expected in the home counties of their party's gubernatorial candidate again suggests that the home counties of gubernatorial candidates are not related to unmeasured party preferences.

Given that only a small number of observations are home counties, another concern is that the coattail effect estimates might be particularly sensitive to the inclusion of certain observations. I address this concern by reestimating the baseline IV model forty different times, each time excluding a state from the analysis. This allows me to assess how much the estimated coattail effect differs from the estimate obtained when all states are included in the regression. The estimated coattail effect ranges from 0.175 (s.e. 0.078), excluding Vermont, to 0.242 (s.e. 0.078), excluding Mississippi, when county time trends are excluded. When county time trends are included, estimates range from 0.130 (s.e. 0.077), excluding Kentucky, to 0.197 (s.e. 0.070), excluding Arkansas. A block jackknife estimator uses the variation across these forty coefficients to estimate a more conservative standard error than

\footnotetext{
${ }^{19}$ The most proximate presidential elections are defined to be those elections that take place one year prior to two years after a gubernatorial election, with observations being dropped if the presidential and gubernatorial elections are held concurrently. For example, presidential vote share in 1988 is regressed on the home counties of gubernatorial candidates in 1987, 1989, and 1990, with observations from 1988 gubernatorial elections being dropped from the analysis.

${ }^{20}$ Similarly, a presidential candidates perform 0.02 (s.e. 0.18 ) percentage points worse than expected in the home counties of their party's gubernatorial candidate when county time trends are included as controls. Full results available from the author upon request.
} 
the robust standard errors clustered by county (Miller, 1974). ${ }^{21}$ The block jackknife standard error estimates are 0.094 and 0.084 when county time trends are excluded and included respectively. These findings suggest that the results reported in Table 3 are not being driven by a small number of observations and that the robust standard errors clustered by county are not dramatically understating the potential influence of sampling error in the baseline specification. $^{22}$

I also undertake additional sensitivity analysis using the local-to-zero method proposed by Conley, Hansen and Rossi (2012) to investigate how IV estimates change as a result of small violations of the exclusion restriction. Rather than assuming that the instruments have no direct effect on down-ballot vote shares, the local-to-zero method allows for IV estimation under any assumed direct effect of the instruments on the dependent variable. ${ }^{23}$ Figure 2 shows how the estimated coattail effect and $95 \%$ confidence interval varies in the baseline IV specifications (i.e., the specifications shown in columns 4 and 5 of Table 3) as a function of the assumed direct effect of gubernatorial home county on down-ballot vote share. The gubernatorial coattail effect remains statistically significant at the $95 \%$ level if the direct effect of gubernatorial home county on down-ballot vote share is less than 0.23 and 0.09 percentage points when county time trends are excluded and included respectively.

I next examine whether gubernatorial candidates perform better in the home counties of down-ballot candidates. If something about the gubernatorial candidate selection process causes gubernatorial candidates' place of birth and residence to relate to unmeasured county-level party preferences, then it seems likely that the down-ballot candidate selec-

\footnotetext{
${ }^{21}$ This block jackknife standard error is more conservative than the robust standard errors clustered by county, in part, because the number of home counties differs across states, and thus it is likely inefficient to weight states equally when constructing the standard error.

${ }^{22}$ There is greater concern that robust standard errors clustered by county will understate the potential influence of sampling error when Within $50_{s, c, t, g o v}$ is also included as an instrument. Because counties located within 50 miles of a home county are in close proximity to each other, these counties may potentially be affected by spatially autocorrelated unobservables. Unlike in the baseline specification, the block jackknife standard errors are about double the magnitude of the robust standard errors clustered by county. While not definitive, this finding suggests that some additional caution should be applied in assessing potential influence of sampling error when Within $50_{s, c, t, g o v}$ is also included as an instrument.

${ }^{23}$ This is done by putting a certain prior on the direct effect being a specific value.
} 
tion process would do the same for down-ballot candidates. If so, gubernatorial candidates should perform better than expected in the home counties of down-ballot candidates from their party. Gubernatorial candidates may also perform better than expected in the home counties of down-ballot candidates from their party because of reverse coattails. However, Table 4 shows that governors do not perform significantly better in the home counties of down-ballot candidates from their party. Much like gubernatorial candidates, secretary of state and attorney general candidates receive about a four percentage point increase in their vote share in their home counties. However, IV estimates of the reverse coattail effect are generally statistically insignificant and negative. ${ }^{24}$ This finding suggests both that reverse coattails are non-existent and that down-ballot candidates are not selected from counties where their party is going to run particularly strong in a given year.

The null IV results in Table 4 contrast with the OLS results that show robust positive associations when a party's gubernatorial vote share in a county is regressed on the party's selected down-ballot vote share in the county. Because previous work frequently interprets OLS coefficients as coattail effects, this creates concern that this work may be overstating the importance of coattails. However, there are some idiosyncratic features of the OLS regressions reported in Table 4 that may make these regressions particularly susceptible to both simultaneity and omitted variable bias. The existence of gubernatorial coattails may bias these OLS estimates upwards because of reserve causality. It is also possible that more flexible time trends are needed to capture changes in the county's normal vote across time. To address these possibilities, I regress the average Democratic vote share in the county in all other down-ballot races (e.g., treasurer and comptroller) on the Democratic vote share in the selected down-ballot race. Because the coattails from other down-ballot candidates onto the secretary of state or attorney general race are thought to be relatively small, the OLS estimates from these regression should be less affected by reverse causality. I also include quadratic, rather than linear, county time trends in some of these analyses to investigate the

\footnotetext{
${ }^{24}$ A marginally significant negative effect of down-ballot vote share on gubernatorial vote share is estimated in one specification.
} 
possibility that the differences between the OLS and IV analyses could be eliminated with more flexible controls for the normal vote.

Despite these modifications, Table 5 continues to show large differences between the OLS and IV estimates of the coattail effect from secretary of state and attorney general candidates onto other down-ballot races. When linear county time trends are included the OLS coefficient on the selected down-ballot vote share is 0.298 (s.e. 0.013), as compared to 0.328 (s.e. 0.019) when gubernatorial vote share is the dependent variable. Using quadratic, rather than linear, county time trends only slightly attenuates this estimate to 0.264 (s.e. 0.015). In contrast, the IV specifications find no evidence of a coattail effect. Moreover, in all of the specifications I can reject the null hypothesis that the OLS and IV coefficients are the same at conventional levels. These findings provide additional evidence that the OLS approach typically used to estimate coattail effects is highly susceptible to omitted variable bias.

A final robustness test looks at whether the effect of gubernatorial coattails on secretary of state and attorney general races generalize to a broader set of down-ballot races. One disadvantage of looking at a broader set of races is that I do not observe the home counties of candidates in other down-ballot races. This is problematic because gubernatorial candidates often hold down-ballot office prior to running for governor, and thus I expect there to be a negative association between a party's geographic advantage in a county in the gubernatorial and a down-ballot race. Failing to account for this relationship will likely cause me to underestimate the coattail effect. This prediction is born out in Table 6, which shows that the estimated gubernatorial coattail effect on the selected down-ballot race decreases when controls for the home counties of secretary of state and attorney general candidates are excluded. In my baseline specification without county time trends, for example, the coattail effect attenuates from 0.216 (s.e. 0.079 ) to 0.207 (s.e. 0.084 ) when down-ballot home county indicators are excluded.

Table 6 shows that when controls for the home counties of secretary of state and attorney 
general candidates are excluded, I find similar estimates of gubernatorial coattail effects on all down-ballot races and on the selected down-ballot race. The point estimates are somewhat smaller on all down-ballot races when only the home-county indicators are used as instruments and slightly larger on all down-ballot races when the nearby counties are also used as instruments. In my baseline specification without county time trends, for example, I find a one-percentage-point increase in a gubernatorial candidate's vote share increases a party's down-ballot vote share in all races by 0.150 (s.e. 0.064) percentage points (column 3), as compared to 0.207 (s.e. 0.084) percentage points in the selected down-ballot race (column 2 ). These findings suggest the gubernatorial coattail effect identified in the selected downballot race is broadly consistent with the gubernatorial coattail effect in other down-ballot statewide executive office races.

\subsubsection{Mechanisms}

This section discusses some potential individual-level mechanisms that underlie friends-andneighbors voting, and their implications for estimates of the coattail effect. The first-stage increase in a candidate's vote share near their place of birth and residence is caused by a combination of three factors: supporters of a local candidate's party voting more, opponents of a local candidate's party voting less, and opponents of a local candidate's party deviating from their usual vote. These different potential sources of the home-county advantage have implications for the coattail effect. An increase in the proportion of voters who support the party of the local candidate is consistent with Campbell's (1960) theory that coattails are caused by top-ballot candidates mobilizing a party's peripheral supporters, who also support the party's down-ballot candidates. In contrast, observing that individuals who are persuaded to support local gubernatorial candidates are also persuaded to support downballot candidates from the party of the local gubernatorial candidate is consistent with Mondak and McCurley's (1994) cognitive dissonance theory.

The aggregated data used in this paper are not well suited for identifying these individual- 
level mechanisms. However, I can shed light on the possible role of mobilization in causing friends-and-neighbors voting. I do this by estimating a modified version of equation 2 in which I replace the home-county indicators with their absolute value and make the dependent variable the natural log of the total votes cast in the selected down-ballot race. The results in Table 7 show that the total number of votes cast in a down-ballot race is significantly higher in the home counties of gubernatorial candidates. The point estimates suggest that the number of down-ballot votes increases by about 2.0 (s.e. 0.6) percent in a gubernatorial candidate's home county, which translates into about a one percentage point increase in turnout when the baseline turnout rate is $50 \%$. This demonstrates that Rice and Macht's (1987b) conclusion that the presence of local candidates on the ballot increases turnout generalizes beyond the 24 gubernatorial elections in 1982 that they study. However, the magnitude of this turnout increase is substantially smaller than the increase in vote share candidates receive in their home counties. Unless having a local candidate also demobilizes voters who would otherwise vote against the local candidate, this suggests that friends-andneighbors voting is primarily caused by persuasion.

The remainder of Table 7 looks at heterogeneity across states and counties in the effect of having a local gubernatorial candidate on down-ballot votes. When the gubernatorial candidate was born or resides in a county, the number of down-ballot votes increases by about 1.1 (s.e 0.9) percent in elections held concurrently with the presidential election, as compared to 2.3 (s.e. 0.7) in non-presidential elections. This pattern suggests some of those individuals mobilized by the presence of local candidates are also mobilized by the presidential election. Table 7 also shows that turnout increases are largest in less populated counties.

While these findings suggest that persuasion is the primary mechanism causing the homecounty advantage, I cannot rule out that mobilization is an important cause of the gubernatorial coattail effect. My estimates of the coattail effect are based on down-ballot candidates performing about one percentage point better in the home counties of gubernatorial can- 
didates from their party. Thus, mobilization could explain all of the coattail effect if the

results in Table 7 are caused by an increase in turnout by peripheral supporters of the local gubernatorial candidate's party. However, it is also possible that the party preferences of these marginal voters roughly mirror the average voter in the county. If this is the case, these extra voters may not contribute to the coattail effect. Thus, I leave it to future research using individual-level data to better sort out the mechanisms that lead to these coattail effects.

\subsection{Discussion}

The results of this paper have important implications for the study of how structural features of the electoral cycle affects representation. The existence of coattail effects suggests that holding concurrent elections can affect the outcome of less salient elections and the incentives of down-ballot candidates to engage in personal vote-seeking behavior. The number of downballot races that may be swung by the personal popularity of top-ballot candidates increases in the magnitude of the coattail effect. Consider the effect of U.S. presidential coattails on House races. Previous estimates generally show that a one-percentage-point increase in a presidential candidate's vote share is associated with a 0.3 to 0.5 percentage-point increase in the vote shares received by his party's House candidates. Interpreting these estimates as coattails implies that when the personal characteristics of a presidential candidate causes his vote share to increase by five percentage points, he can lead his party's House candidate to victory who might otherwise lose by up to five percentage points. Using OLS, I estimate similar associations between gubernatorial and down-ballot statewide executive office candidates. However, my IV point estimates indicate that a five-percentage-point increase in the personal vote received by a gubernatorial candidate affects only the outcome of down-ballot elections in which her party would otherwise lose by fewer than two percentage points. The difference suggests that interpreting these previous estimates as coattails may substantially overstate the effect of presidential candidates on House elections.

The existence of coattail effect may also alter the incentives of down-ballot office holders 
to represent their constituents' interests. The existence of a significant coattail effect raises the question of whether the electoral fortunes of down-ballot office holders are tied too closely to concurrently elected gubernatorial candidates for there to be incentives to represent their constituents interests. In the extreme case where down-ballot votes are simply a reflection of vote choice in the top-ballot election, there is no relationship between a down-ballot office holder's performance in office and whether he or she is reelected. Under such a scenario, coattail effects would eliminate the incentive for down-ballot office holders to engage in personal vote seeking behavior. A more complete model of elections is needed to understand the consequences of my estimates of the coattail effect on the incentives of down-ballot office holders to represent their constituents. However, my finding that the presence of a concurrent presidential election has no effect on the magnitude of friends-and-neighbors voting in gubernatorial or down-ballot races shows that one form of personal voting is not crowded out by coattails.

Finally, my findings have implications for the research designs that scholars use to study the personal vote. An appealing empirical strategy for estimating the amount of personal voting is to look at how a party's vote share within a constituency varies across concurrent elections as a function of characteristics of the candidates in a race (Ansolabehere and Snyder, 2002; Gerber, Kessler and Meredith, 2011). However, the presence of coattails introduces the potential for omitted variable bias when using such a design, implying that down-ballot races do not make good control races from which to estimate the personal vote in gubernatorial races. However, the lack of coattails generated by down-ballot statewide races like attorney general and secretary of state means that these elections may make good control races from which to estimate the personal vote in other down-ballot races. 


\section{Conclusion}

This paper demonstrates that while top-ballot candidates can influence the outcome of concurrent elections, their influence may be smaller than previously thought. Consistent with previous work, I find robust large associations when I regress a party's vote share in one race on their vote share in a concurrent race. But while previous work frequently interprets such an association as a coattail effect, my results cast doubt on this interpretation. For example, such an interpretation would lead someone to conclude that the coattails of gubernatorial and secretary of state candidates are of a similar magnitude. This also highlights the danger in assessing the relative influence of candidate spillovers on races by comparing regression coefficients. For example, Samuels (2000) regresses a party's vote share in a down-ballot election in Brazil on the party's vote share in concurrent presidential and gubernatorial elections, and concludes that gubernatorial coattails are more than twice as strong as presidential coattails because the coefficient on gubernatorial vote share is more that double the coefficient on presidential vote share.

In contrast, my IV approach provides clear evidence of gubernatorial coattail effects. My

point estimates indicate that a one percentage point increase in the personal vote received by a gubernatorial candidate increases the vote share of secretary of state and attorney general candidates from their party by 0.1 to 0.2 percentage points. These point estimates are somewhat smaller than the estimates obtained from corresponding OLS regressions, although the OLS and IV estimates are generally statistically indistinguishable. These IV estimates are relatively robust to inclusion of county time trends and to alternative specifications. Unlike the OLS regressions, the IV regressions show no effect of personal votes received by secretary of state or attorney general candidates on the performance of other candidates from their party. Moreover, placebo tests show that the instruments do not predict a party's performance in other elections. These additional analyses strengthen my claim that the IV regressions are identifying coattail effects rather than unmeasured partisan preferences. My findings also suggest that the methods commonly used to measure contamination effects are 
too susceptible to omitted variable and simultaneity bias to produce reliable estimates of contamination effects.

The method used in this paper is both straightforward to implement and portable to other election contexts in the United States and abroad. Because friends-and-neighbors voting has been demonstrated in many electoral contexts, the effect can be used to compare how the magnitude of coattail effects varies across different offices, electoral systems, and types of voters. Other candidate characteristics that systematically relate to candidate preferences can also be incorporated into the analysis as additional instruments. For example, the match between a candidate's religious affiliation and the religious demographics of a county may potentially isolate personal votes cast on the basis of a candidate's religion.

More generally, this paper shows the importance of careful research design when measuring spillovers. Theories of spillovers are pervasive in the study of political science. Coattails are just one of the many contamination effects that are posited to occur across multilevel governments. Beyond the study of elections, policy change in one state is hypothesized to influence policies in neighboring states, partisan identification when young is believed to affect political preferences later in life, and social capital is thought to be transmitted through interpersonal networks. Estimating the magnitude of such spillovers is generally quite difficult because a relationship between the two outcomes is expected even in the absence of spillovers. Researchers are aware of this problem and address it by including additional control variables in most tests of spillovers (Hainmueller and Kern, 2008). Yet, most studies pay insufficient attention to whether their specific set of control variables plausibly account for all these joint determinants. In particular, researchers should make greater use of robustness analysis, similar to that used in section 4.2.2, to strengthen their case for making causal statements about spillovers in observational data.

Finally, this paper provides a general blueprint for estimating spillover effects in observational data. I use previous literature to identify a relatively idiosyncratic source of variation in the outcome that I expect to spillover. The best case scenario of such an approach is that 
it uncovers something that approximates experimental variation in the outcome. However even when this does not occur, focusing on a specific source of variation in an outcome can greatly reduce the set of control variables that must be included in order to prevent omitted variable bias when estimating spillover effects. This approach made it so that I only needed to control for the factors that affect gubernatorial home counties and down-ballot vote shares, rather than all of the factors that affect gubernatorial and down-ballot vote shares more generally. ${ }^{25}$ For example, I did not necessarily have to model the effects of variables like economic conditions, which are known to affect partisan preferences in both top- and down-ballot races, but are plausibly unrelated to candidate selection. Moreover the relative stability of my estimates of the friends-and-neighbors vote to the inclusion of control variables like county time trends provides support for my claim that a relatively sparse set of controls can account for the joint determinants of gubernatorial home counties and down-ballot vote shares.

I conclude by cautioning that this approach is not without costs. The bias resulting from of any remaining omitted variables is amplified when using IV. The LATE property of IV estimation also means that the coattail effect identified for friends-and-neighbors voters may not apply to other personal voters, such as those who select a gubernatorial candidate on the basis of their religious preference or the attractiveness of their facial features. Thus, IV results should always be benchmarked against an OLS specification that attempts to control for as many observable joint determinants as possible. In cases where these OLS and IV regressions produce different findings, one should not necessarily conclude that the OLS results are incorrect. But particularly in situations where data quality is poor or outcomes are thought to contaminate each other, it is difficult to convincingly demonstrate the existence of spillovers only on the basis of these OLS regression. Thus while my approach lacks some of the internal and external validity associated with experiments, it provides a good alternative

\footnotetext{
${ }^{25}$ Similarly, a number recent studies estimate contamination effects using close election regression discontinuity designs (Hainmueller and Kern, 2008; Broockman, 2009; Ade and Freier, 2011). Rather then modeling the joint determinants of two elections outcomes, these studies isolate variation in the outcome of one of the elections that results from one party receiving slightly more votes than another party.
} 
for estimating spillovers when experimentation is not feasible, ethical, or cost-effective. 


\section{References}

Ade, Florian and Ronny Freier. 2011. Divided government versus incumbency externality effect: Quasi-experimental evidence on multiple voting decisions. German Institute for Economic Research Discussion Paper 1121.

Ames, Barry. 1994. "The reverse coattails effect: Local party organization in the 1989 Brazilian presidential election." American Political Science Review 88(1):95-111.

Ansolabehere, Stephen and James M. Snyder. 2002. "The incumbency advantage in U.S. elections: An analysis of state and federal offices, 1942-2000." Election Law Journal 1(3):315338.

Bean, Louis H. 1948. How to predict elections. New York : Alfred A. Kropf.

Berry, Christopher R. and Jacob E. Gersen. 2010. "The timing of elections." University of Chicago Law Review 77(1):37-64.

Born, Richard. 1984. "Reassessing the decline of presidential coattails: U. S. House elections from 1952-80." Journal of Politics 46(1):60-79.

Broockman, David E. 2009. "Do congressional candidates have reverse coattails? Evidence from a regression discontinuity design." Political Analysis 17(4):418-434.

Brown, Adam R. 2011. "Wikipedia as a data source for political scientists: Accuracy and completeness of coverage." PS: Political Science \& Politics 44(2):339-343.

Cain, Bruce, John Ferejohn and Morris Fiorina. 1990. The personal vote. Harvard University Press.

Calvert, Randall L. and John A. Ferejohn. 1983. "Coattail voting in recent presidential elections." American Political Science Review 77(2):407-419.

Cameron, A. Colin, Jonah B. Gelbach and Douglas L. Miller. 2011. "Robust inference with multiway clustering." Journal of Business E Economic Statistics 29(2):238-249.

Campbell, Angus. 1960. "Surge and decline: A study of electoral change." Public Opinion Quarterly 24(3):397-418.

Campbell, Angus and Warren E. Miller. 1957. "The motivational basis of straight and split ticket voting." American Political Science Review 51(2):293-312.

Campbell, James E. 1991. "The presidential surge and its midterm decline in congressional elections, 1868-1988." Journal of Politics 53(2):477-487.

Campbell, James E. and Joe A. Sumners. 1990. "Presidential coattails in senate elections." American Political Science Review 84(2):513-524.

Conley, Timothy G., Christian B. Hansen and Peter E. Rossi. 2012. "Plausibly exogenous." Review of Economics and Statistics 94(1):260272. 
Converse, Philip E. 1966. The concept of the normal vote. In Elections and the political order, ed. Angus Campbell, Philip E. Converse, Warren E. Miller and Donald E. Stokes. New York: John Wiley and Sons, Inc.

Cox, Gary W. 1999. "Electoral rules and the calculus of mobilization." Legislative Studies Quarterly 24(3):387-419.

Cox, Karen E. and Leonard J. Schoppa. 2002. "Interaction effects in mixed-member electoral systems." Comparative Political Studies 35(9):1027-1053.

Fair, Ray C. 2009. "Presidential and congressional vote-share equations." American Journal of Political Science 53(1):55-72.

Ferejohn, John A. and Randall L. Calvert. 1984. "Presidential coattails in historical perspective." American Journal of Political Science 28(1):127-146.

Ferrara, Federico, Erik S. Herron and Misa Nishikawa. 2005. Mixed electoral systems: Contamination and its consequences. Palgrave Macmillian.

Flemming, Gregory N. 1995. "Presidential coattails in open-seat elections." Legislative Studies Quarterly 20(2):197-211.

Folke, Olle and James M. Snyder. 2012. "Gubernatorial midterm slumps." American Journal of Political Science 56:4.

Freedman, Paul, Michael Franz and Kenneth Goldstein. 2004. "Campaign advertising and democratic citizenship." American Journal of Political Science 48(4):723-741.

Gerber, Alan S., Daniel P. Kessler and Marc Meredith. 2011. "The persuasive effects of direct mail: A regression discontinuity based approach." Journal of Politics 73(1):140-155.

Gimpel, James G., Kimberly A. Karnes, John McTague and Shanna Pearson-Merkowitz. 2008. "Distance-decay in the political geography of friends-and-neighbors voting." Political Geography 27(2):231-252.

Golder, Matt. 2006. "Presidential coattails and legislative fragmentation." American Journal of Political Science 50(1):34-48.

Hainmueller, Jens and Holger Lutz Kern. 2008. "Incumbency as a source of spillover effects in mixed electoral systems: Evidence from a regression-discontinuity design." Electoral Studies 27(2):213-227.

Herron, Erik S. and Misa Nishikawa. 2001. "Contamination effects and the number of parties in mixed-superposition electoral systems." Electoral Studies 20(1):63-86.

Hicken, Allen and Heather Stoll. 2011. "Presidents and parties: How presidential elections shape coordination in legislative elections." Comparative Political Studies 44(7):854-883.

Hogan, Robert E. 2005. "Gubernatorial coattail effects in state legislative elections." Political Research Quarterly 58(4):587-597. 
Imbens, Guido W. and Joshua D. Angrist. 1994. "Identification and estimation of local average treatment effects." Econometrica 62(2):467-475.

Jacobson, Gary C. 1976. "Presidential coattails in 1972." Public Opinion Quarterly 40(2):194-200.

Key, V. O. 1949. Southern politics in state and nation. New York: A. A. Knopf.

Kramer, Gerald H. 1971. "Short-term fluctuations in US voting behavior, 1896-1964." American Political Science Review 65(1):131-143.

Levitt, Steven D. and Catherine D. Wolfram. 1997. "Decomposing the sources of incumbency advantage in the U.S. house." Legislative Studies Quarterly 22(1):45-60.

Lewis-Beck, Michael S. and Tom W. Rice. 1983. "Localism in presidential elections: The home state advantage." American Journal of Political Science 27(3):548-556.

Magar, Eric. 2012. "Gubernatorial coattails in Mexican congressional elections." Journal of Politics 74(2):383-399.

Mattei, Franco and Joshua Glasgow. 2005. "Presidential coattails, incumbency advantage, and open seats: A district-level analysis of the 19762000 U.S. House elections." Electoral Studies 24(4):619-641.

Miller, Arthur H. 1979. "Normal vote analysis: Sensitivity to change over time." American Journal of Political Science 23(2):406-425.

Miller, Rupert G. 1974. "The jackknife-A review." Biometrika 61(1):1-15.

Miller, Warren E. 1955. "Presidential coattails: A study in political myth and methodology." Public Opinion Quarterly 19(4):353-368.

Mondak, Jeffery J. 1993. "Presidential coattails and open seats: The district-level impact of heuristic processing." American Politics Research 21(3):307-319.

Mondak, Jeffery J. and Carl McCurley. 1994. "Cognitive efficiency and the congressional vote: The psychology of coattail voting." Political Research Quarterly 47(1):151-175.

Moos, Malcolm. 1952. Politics, presidents, and coattails. Baltimore: John Hopkins Press.

Rahn, Wendy M., Jon A. Krosnick and Marijke Breuning. 1994. "Rationalization and derivation processes in survey studies of political candidate evaluation." American Journal of Political Science 38(3):582-600.

Rice, Tom W. and Alisa A. Macht. 1987a. "Friends and neighbors voting in statewide general elections." American Journal of Political Science 31(2):448-452.

Rice, Tom W. and Alisa A. Macht. 1987b. "The hometown advantage: Mobilization or conversion?" Political Behavior 9(3):257-262. 
Rusk, Jerrold G. 1970. "The effect of the australian ballot reform on split ticket voting: 1876-1908." American Political Science Review 64(4):1220-1238.

Samuels, David J. 2000. "The gubernatorial coattails effect: Federalism and congressional elections in Brazil." Journal of Politics 62(1):240-253.

Samuels, David J. 2002. "Presidential parties: The seperation of powers and party organzation and behavior." Comparative Political Studies 35(4):461-483.

Samuels, David J. 2003. Ambition, federalism, and legislative politics in Brazil. Cambridge University Press.

Samuels, David J. 2004. "Presidentialism and accountability for the economy in comparative perspective." American Political Science Review 98(3):425-436.

Shugart, Matthew S. and John M. Carey. 1992. Presidents and assemblies: Constitutional design and electoral dynamics. Cambridge University Press.

Sovey, Allison J. and Donald P. Green. 2011. "Instrumental variables estimation in political science: A readers guide." American Journal of Political Science 55(1):188-200.

Stock, James H., Jonathan H. Wright and Motohiro Yogo. 2002. "A survey of weak instruments and weak identification in generalized method of moments." Journal of Business and Economic Statistics 20(4):518-529.

Wolak, Jennifer. 2009. "The consequences of concurrent campaigns for citizen knowledge of congressional candidates." Political Behavior 31:211-229.

Zudenkova, Galina. 2011. "A political agency model of coattail voting." Journal of Public Economics 95(1112):1652-1660. 


\section{$6 \quad$ Figures and Tables}

Figure 1: Average Vote Shares in Gubernatorial Candidates' Home Counties

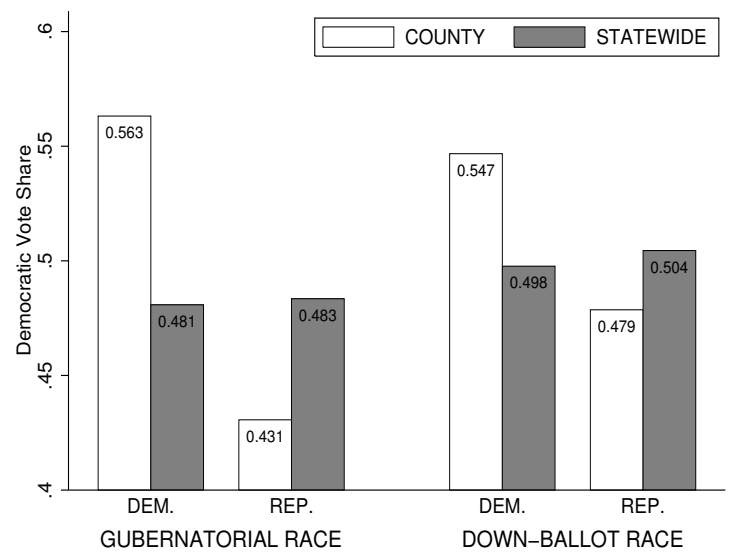

(a) Elections with Gubernatorial Candidate from County

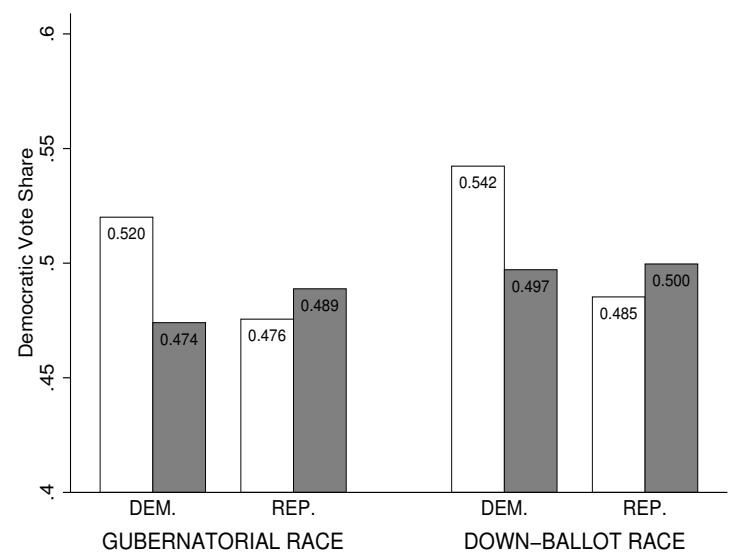

(b) Elections without Gubernatorial Candidate from County

Notes: The top panel plots the average vote share that a party's candidates receive in a home county of their current gubernatorial candidate. The bottom panel plots the average vote share that a party's candidates receive in these same counties in elections when the county is neither a home county of the Democratic nor the Republican gubernatorial candidate. Sample includes 202 home counties if Democratic gubernatorial candidates and 196 home counties of Republican gubernatorial candidates. 
Figure 2: Estimated Coattail Effect under Alternative Identification Assumptions

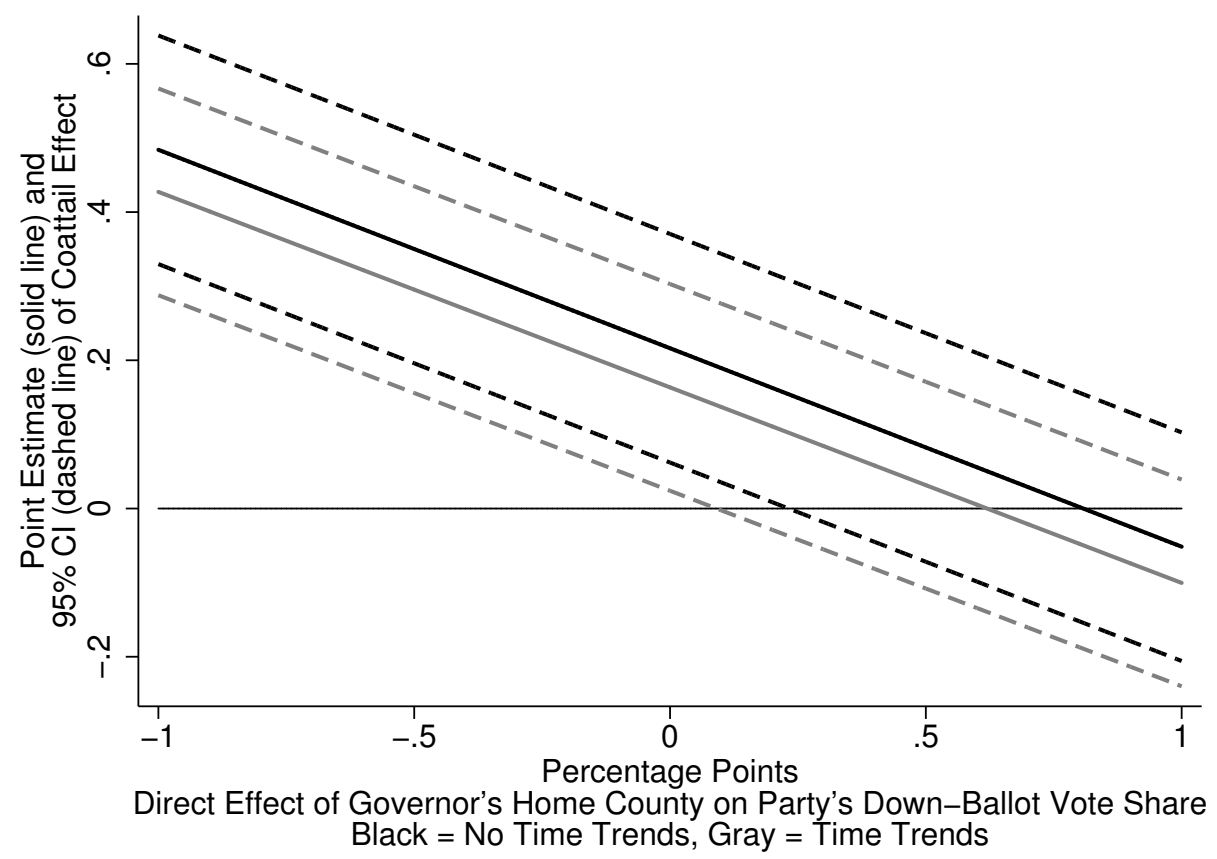

Notes: The standard IV assumption is that a gubernatorial candidate's home county has no direct effect on a party's down-ballot vote share (i.e. a gubernatorial candidate's home county only affects down-ballot vote share because of coattails). The black line represents the point estimate and the dotted lines represent the $95 \%$ confidence interval of the estimated coattail effect assuming alternative direct effects. 


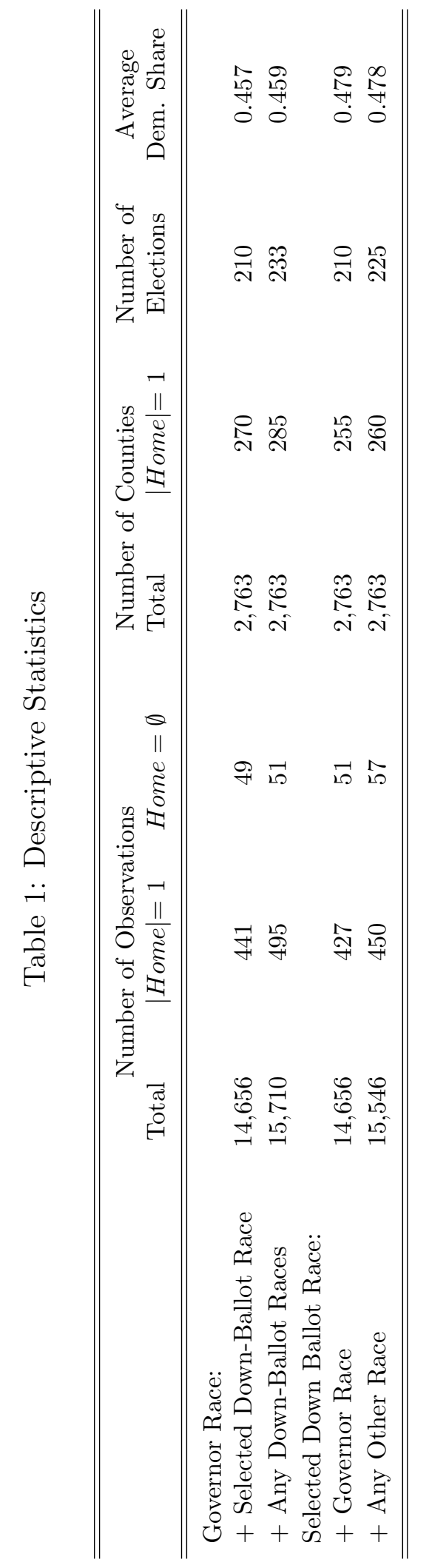




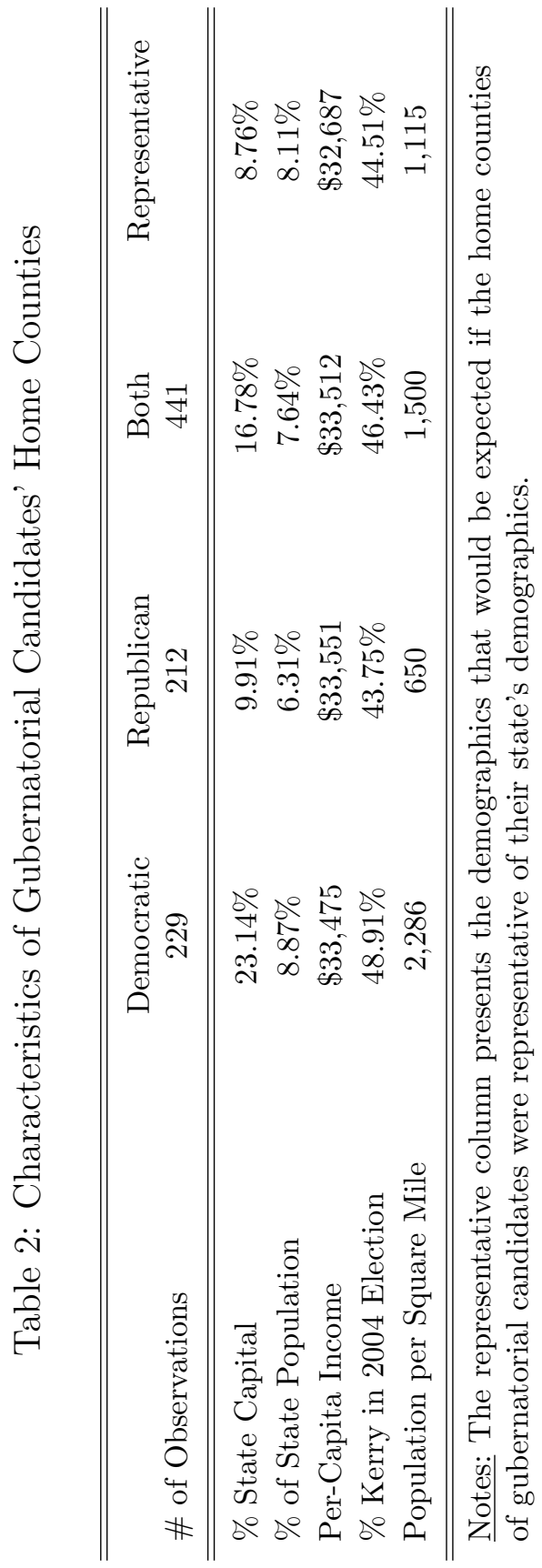




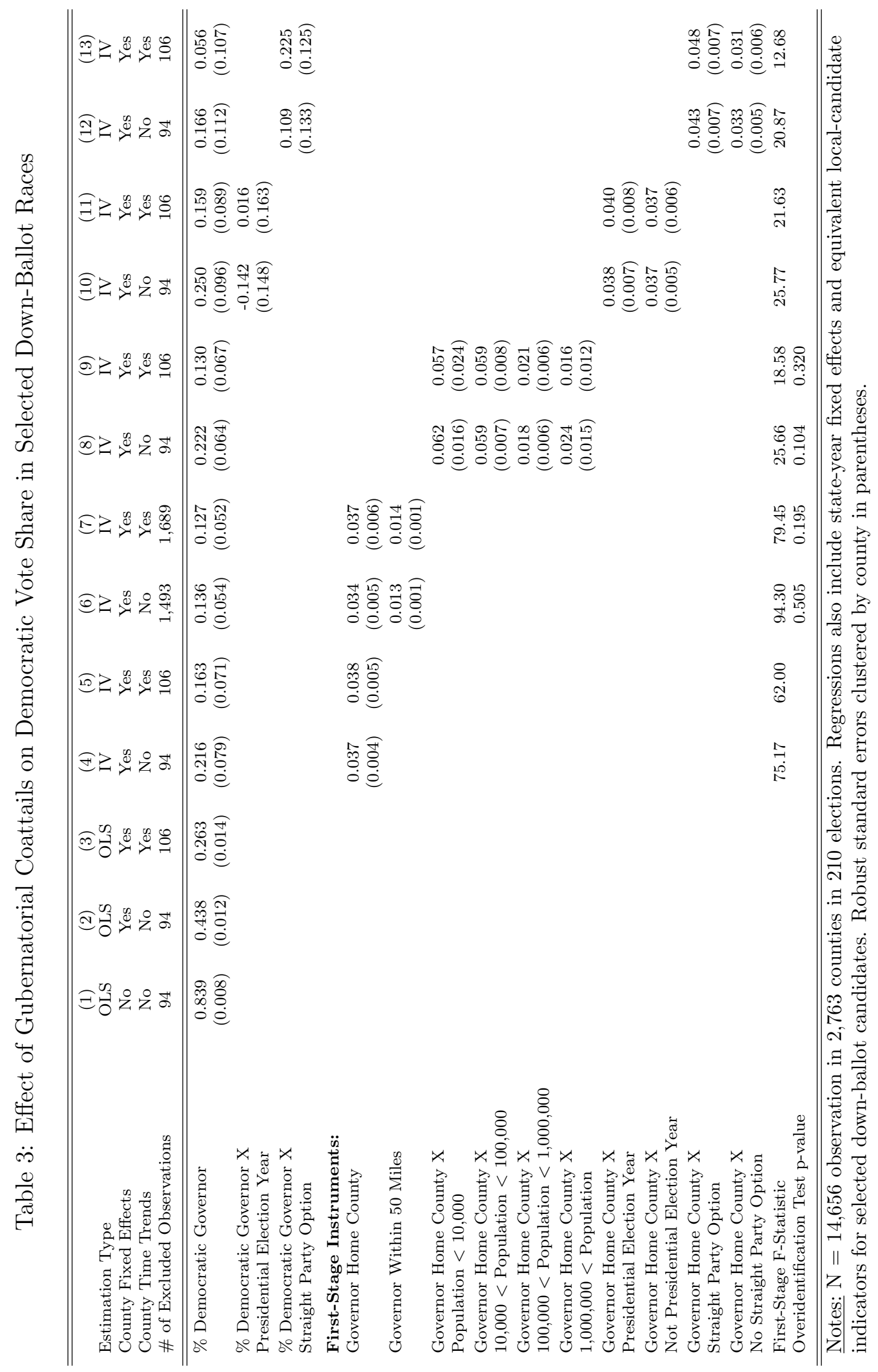




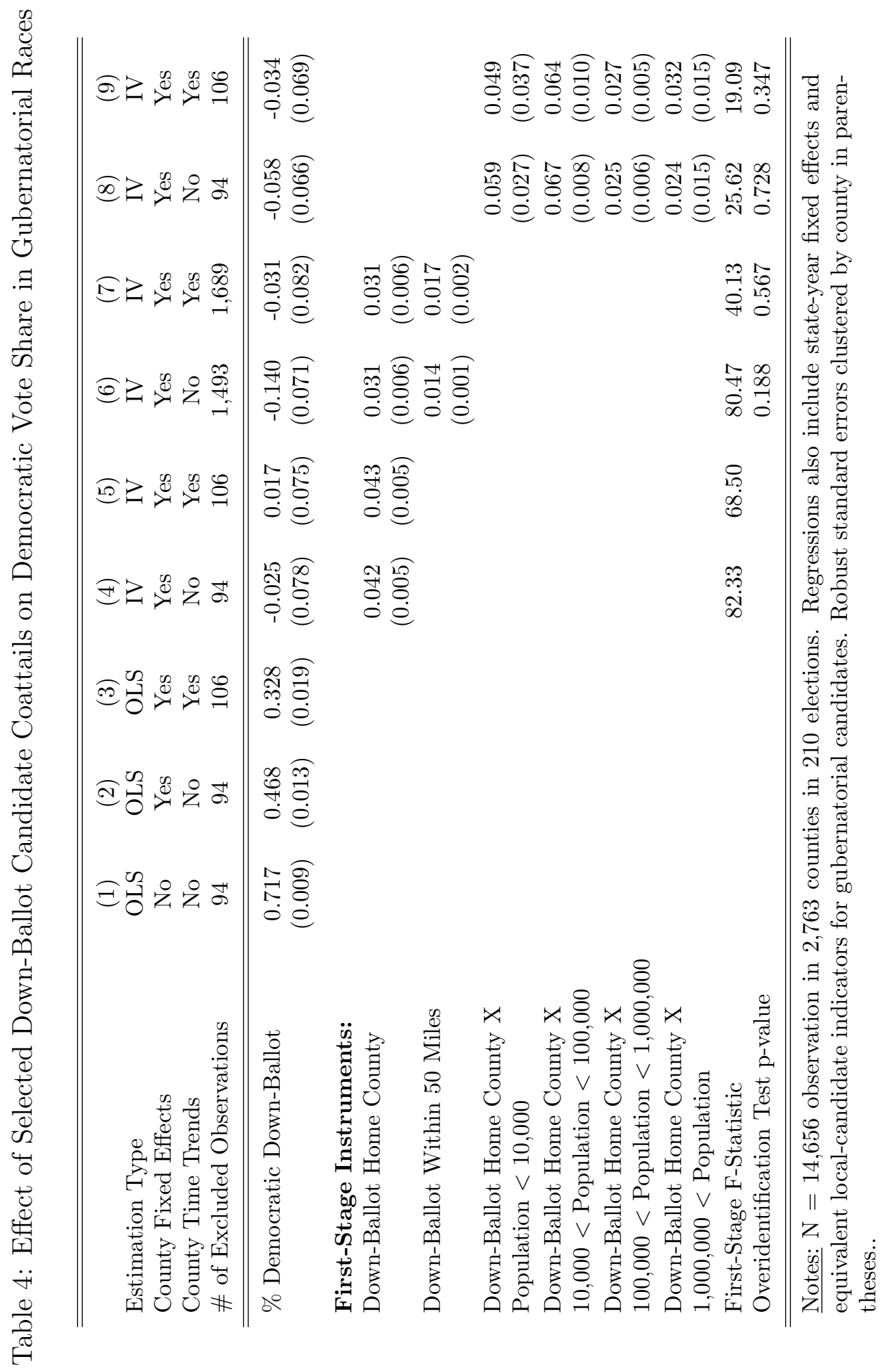




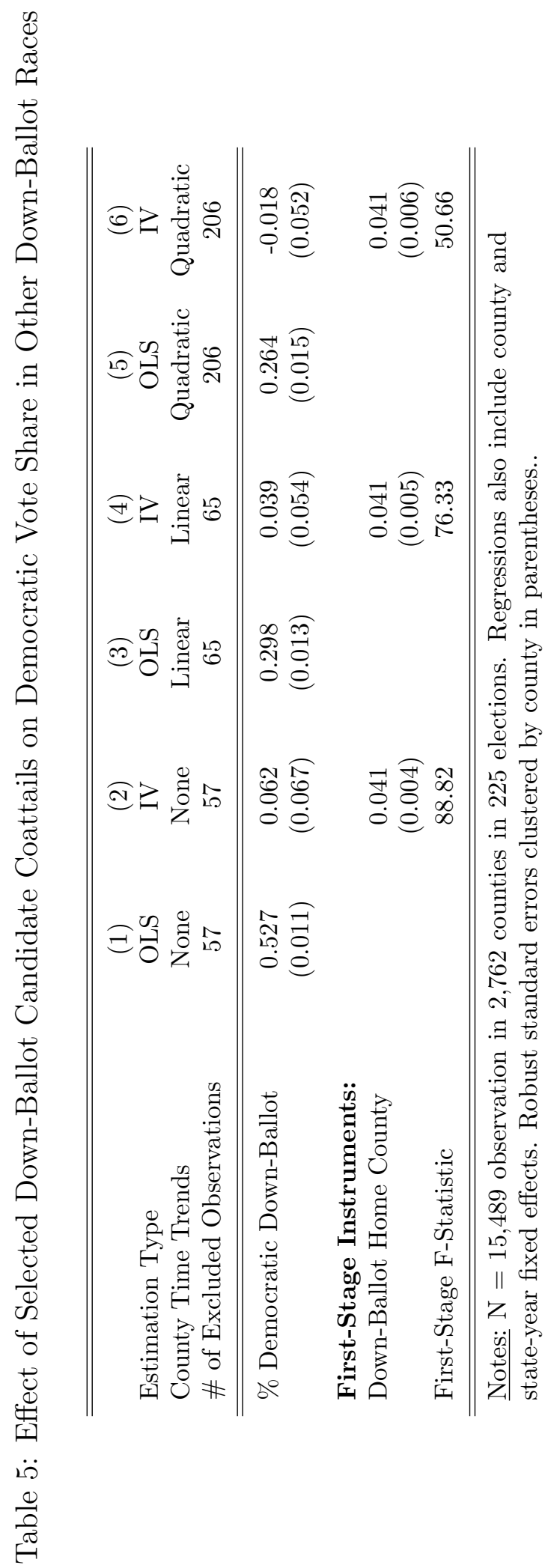




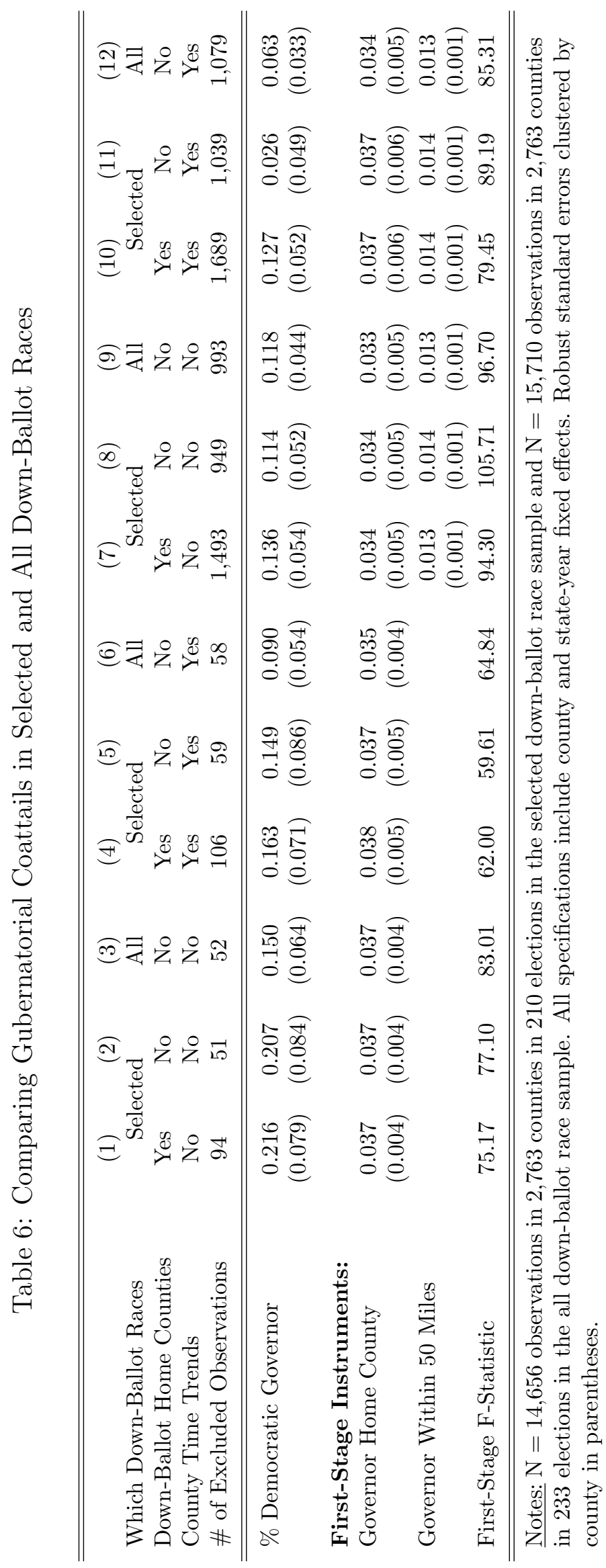


Table 7: Effect of Local Candidates on Logged Votes in Selected Down-Ballot Races

\begin{tabular}{|c|c|c|c|c|c|}
\hline $\begin{array}{l}\text { County Time Trends } \\
\text { \# of Excluded Observations }\end{array}$ & $\begin{array}{l}(1) \\
\text { No } \\
94\end{array}$ & $\begin{array}{l}(2) \\
\text { Yes } \\
106\end{array}$ & $\begin{array}{c}(3) \\
\text { Yes } \\
1,689\end{array}$ & $\begin{array}{l}(4) \\
\text { Yes } \\
106\end{array}$ & $\begin{array}{c}(5) \\
\text { Yes } \\
106\end{array}$ \\
\hline Governor Home County & $\begin{array}{c}0.025 \\
(0.007)\end{array}$ & $\begin{array}{c}0.020 \\
(0.006)\end{array}$ & $\begin{array}{c}0.019 \\
(0.007)\end{array}$ & & \\
\hline Down-Ballot Home County & $\begin{array}{c}0.011 \\
(0.007)\end{array}$ & $\begin{array}{c}0.009 \\
(0.005)\end{array}$ & $\begin{array}{c}0.003 \\
(0.007)\end{array}$ & & \\
\hline Governor Within 50 Miles & & & $\begin{array}{c}0.004 \\
(0.003)\end{array}$ & & \\
\hline Down-Ballot Within 50 Miles & & & $\begin{array}{c}0.003 \\
(0.003)\end{array}$ & & \\
\hline Governor Home County X & & & & 0.011 & \\
\hline Presidential Election Year & & & & $(0.009)$ & \\
\hline Governor Home County X & & & & 0.023 & \\
\hline Not Presidential Election Year & & & & $(0.007)$ & \\
\hline Down-Ballot Home County & & & & 0.015 & \\
\hline Presidential Election Year & & & & $(0.013)$ & \\
\hline Down-Ballot Home County & & & & 0.008 & \\
\hline Not Presidential Election Year & & & & $(0.005)$ & \\
\hline Governor Home County X & & & & & 0.026 \\
\hline Population $<10,000$ & & & & & $(0.024)$ \\
\hline Governor Home County X & & & & & 0.025 \\
\hline $10,000<$ Population $<100,000$ & & & & & $(0.008)$ \\
\hline Governor Home County X & & & & & 0.020 \\
\hline $100,000<$ Population $<1,000,000$ & & & & & $(0.009)$ \\
\hline Governor Home County X & & & & & -0.008 \\
\hline $1,000,000<$ Population & & & & & $(0.019)$ \\
\hline Down-Ballot Home County X & & & & & -0.008 \\
\hline Population $<10,000$ & & & & & $(0.041)$ \\
\hline Down-Ballot Home County X & & & & & 0.006 \\
\hline $10,000<$ Population $<100,000$ & & & & & $(0.008)$ \\
\hline Down-Ballot Home County X & & & & & 0.014 \\
\hline $100,000<$ Population $<1,000,000$ & & & & & $(0.006)$ \\
\hline Down-Ballot Home County X & & & & & 0.004 \\
\hline $1,000,000<$ Population & & & & & $(0.019)$ \\
\hline
\end{tabular}

Notes: $\mathrm{N}=14,656$ observation in 2,763 counties in 210 elections. Regressions also include county and state-year fixed effects. Robust standard errors clustered by county in parentheses. 


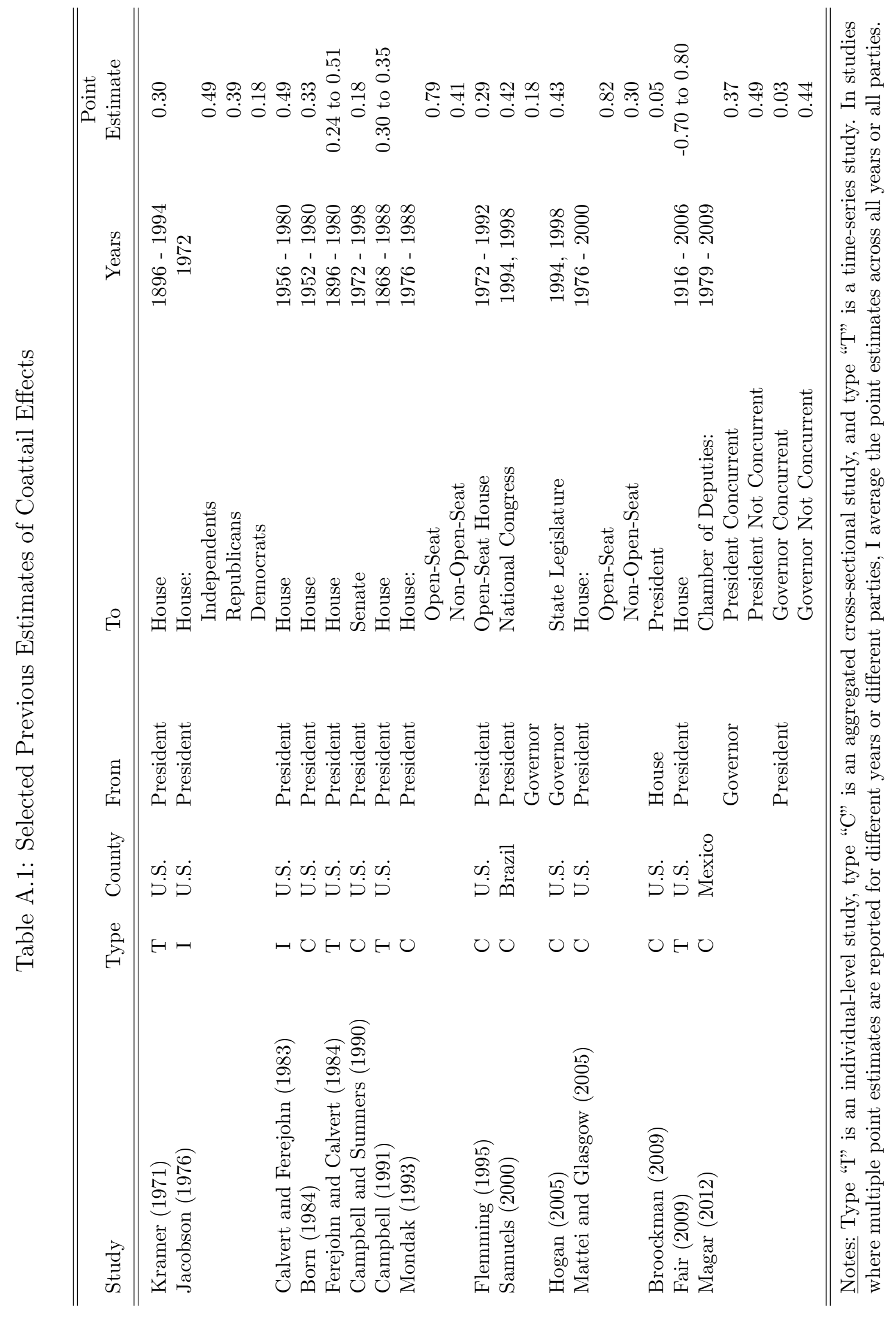




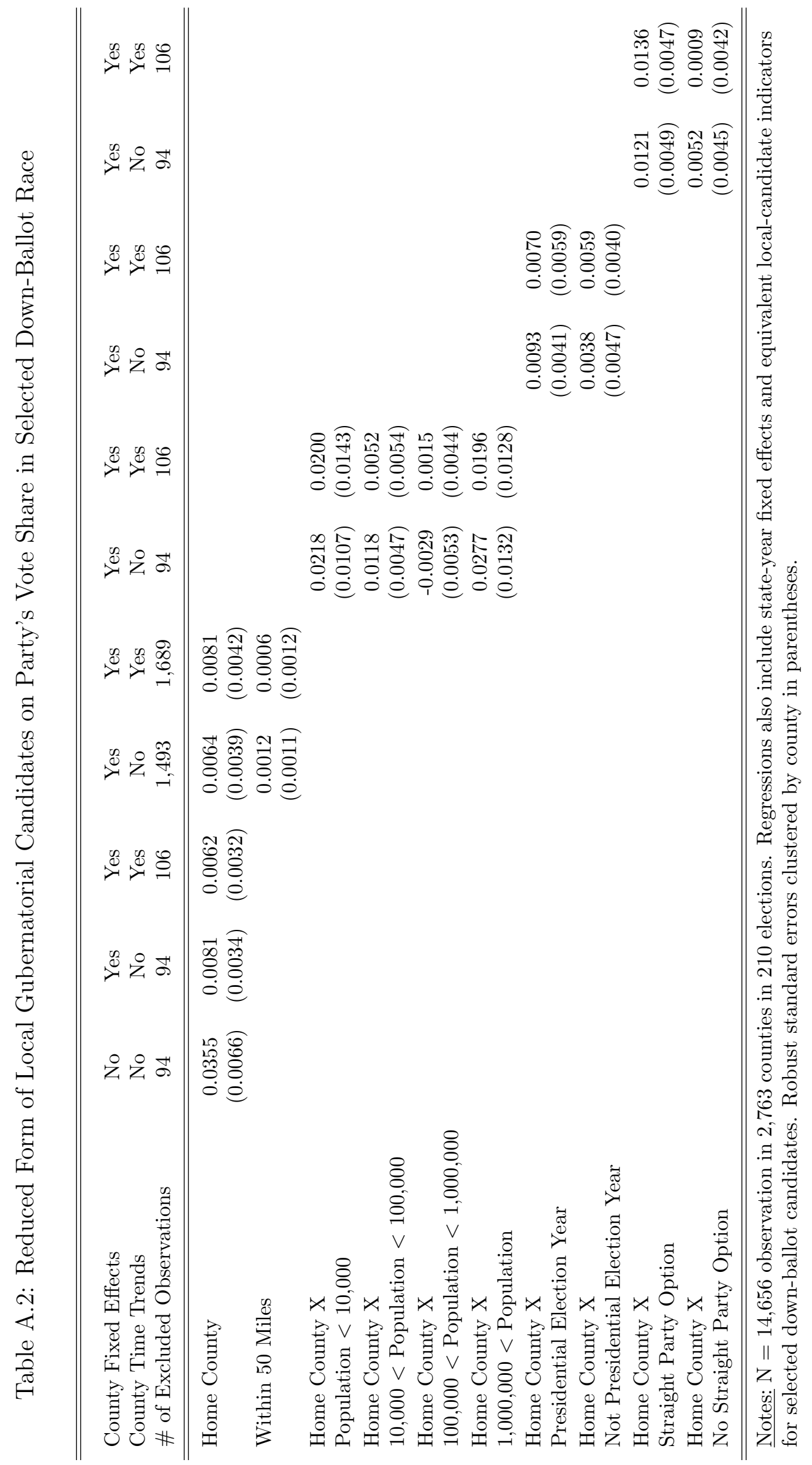




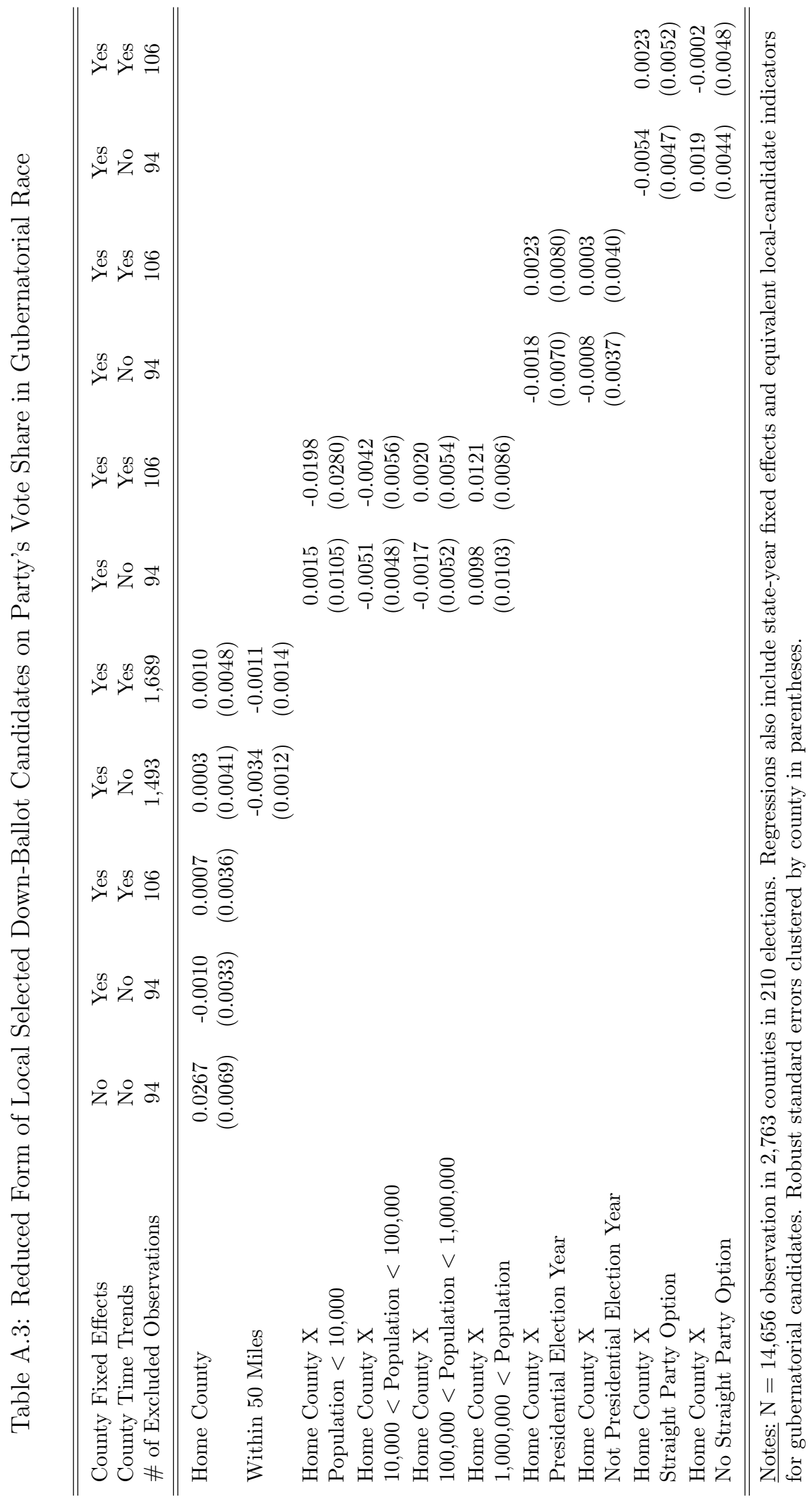




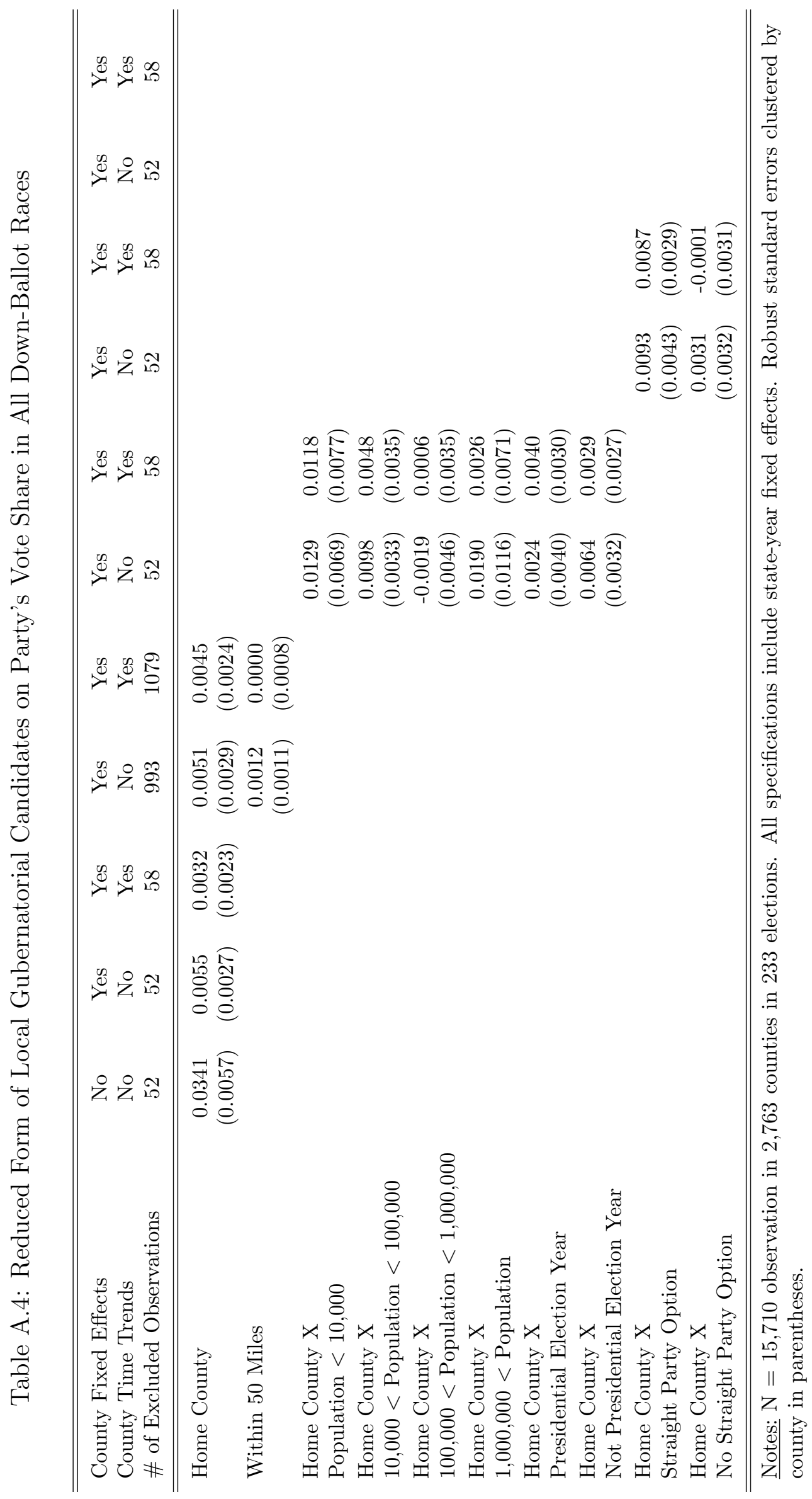

